International Workshop on

The Balance Sheet of Social Security Pensions

\title{
Pension Expenditure Projections, Pension Liabilities and European Union Fiscal Rules
}

\author{
By \\ Daniele Franco, Maria Rosaria Marino and Stefania Zotteri ${ }^{*}$
}

Organised

by

PIE and COE/RES, Hitotsubashi University

Hitotsubashi Collaboration Center, Tokyo, Japan, $1^{\text {st }}-2^{\text {nd }}$ November 2004

Economic Research Department, Banca d'Italia. The views expressed in this paper are those of the authors and do not commit the Banca d'Italia. 


\title{
Pension Expenditure Projections, Pension Liabilities and European Union Fiscal Rules
}

\author{
Daniele Franco, Maria Rosaria Marino and Stefania Zotteri*
}

\section{(Preliminary draft)}

\begin{abstract}
In the current debate on the European Union (EU) fiscal rules there is a widespread consensus on the need to place more focus on government debt and long-term fiscal sustainability in the surveillance of budgetary positions. More specifically, pension developments should be taken into account in assessing fiscal sustainability. The way to make this operational has not yet been defined. The paper examines the pension expenditure projections available in EU countries and their use in the assessment of fiscal sustainability. While acknowledging the progress in the availability and quality of projections, the paper notes that their comparability is still unsatisfactory. Any mechanical use of existing pension expenditure projections should therefore be avoided. The paper also examines the different definitions of pension liabilities and their potential role in the EU fiscal framework. It argues that pension liabilities may bring a clearer understanding of the impact of fiscal policies, may provide a measure of the cost of terminating pay-as-you-go pension schemes and may be useful for the measurement of deficits computed on accrual basis. However, the level of pension liabilities does not provide indications concerning the sustainability of pension schemes and their effects on public budgets. Pension liabilities should not be added to conventional debt. The paper argues that both pension expenditure projections and estimates of pension liabilities can complement the deficit and debt indicators currently used in the EU fiscal rules. The paper concludes by pointing to the need of improving some technical and organisational aspects concerning age-related expenditure projections, such as the independence of forecasters, the transparency of projections and the homogeneity of methods.
\end{abstract}

Economic Research Department, Banca d'Italia. The views expressed in this paper are those of the authors and do not commit the Banca d'Italia. 


\section{Introduction}

The search for rules and procedures that ensure sound budgetary positions has been at the core of the development of the fiscal framework of the European Economic Monetary Union (EMU). Since the early 1990s budgetary discipline has been recognised as an essential condition for the success of EMU. In 1992 the Treaty of Maastricht set the deficit and debt conditions for access to EMU. The Stability and Growth Pact (SGP), adopted by the European Council in Amsterdam in June 1997, complemented the Treaty with a view to reconcile permanent restraint of deficit and debt levels with margins for fiscal stabilisation policies. The Pact also strengthened the monitoring procedures accompanying the quantitative rules.

EMU's fiscal framework demands more than what is strictly necessary for sustainability. This reflects, inter alia, the ambiguity of the economic theory on fiscal sustainability and the multinational dimension of EMU. This pragmatic solution can increase the scope for stabilisation policies with respect to the recent past and contribute to allowing EU countries to meet the budgetary pressures caused by the ageing of their population on a sounder fiscal position.

In recent years, several suggestions to assign a greater role to long-term sustainability in the EMU framework have been put forward. A widespread consensus on the need to place more focus on government debt and sustainability in the surveillance of budgetary positions seems also to emerge from the current debate on the EU fiscal rules. This point has been raised by the European Commission, the European Council, the IMF and the OECD. According to these institutions, a properly grounded sustainability analysis should take into account the effects of population ageing on public finances. In particular, pension expenditure developments should be considered.

Future expenditure trends can be integrated into fiscal sustainability analysis in many ways. This paper aims at contributing to the current debate by exploring the role of pension expenditure projections and of pay-as-you-go pension (PAYG) liabilities.

The paper notes that sustainability issues should be primarily addressed by considering the projections concerning the pension expenditure-to-GDP ratio and the contribution rate that assures the cash balance of pension schemes. However, in view of the still unsatisfactory comparability of pension expenditure projections (across countries and across research centres), the paper suggests to avoid any mechanical use of existing projections. It also suggests improving some technical and organisational aspects concerning age-related expenditure projections, such as the independence of forecasters, the transparency of projections and the homogeneity of methods used.

A more radical solution would require assimilating PAYG pension liabilities to public debt, to consider social contributions as loans to public pension schemes and pension spending as loan repayments. After having examined the different definitions of pension liabilities and their economic implications, the paper argues that the level of pension liabilities does not provide indications concerning the sustainability of current pension policies and the effects of pension schemes on public budgets. Therefore, the paper argues that pension liabilities should not be added 
to conventional debt. Moreover, current estimates of pension liabilities present the same problems affecting the quality and comparability of pension expenditure projections.

Rather, the paper suggests complementing the current deficit and debt indicators with additional indicators concerning future budgetary developments and a broader definition of public sector liabilities. In this context, estimates of pension liabilities may represent a useful complement to conventional fiscal indicators. They may bring a clearer understanding of the impact of fiscal policies, may provide a measure of the cost of terminating pay-as-you-go pension schemes and may be useful for the measurement of deficits computed on accrual basis.

Section 2 briefly surveys the approach to fiscal sustainability taken by the European Union. Section 3 examines the pension expenditure projections available in EU countries. Section 4 considers the different definitions of pension liabilities, the indications that they provide and overviews the existing estimates. Section 5 compares pension expenditure projections and pension liabilities in view of the assessment of fiscal sustainability in the EU framework. Section 6 highlights further progress needed in both pension expenditure projections and pension liabilities estimates. Section 7 concludes.

\section{Fiscal sustainability in EMU}

2.1 The EU approach to sustainability. -Fiscal soundness is the main objective of EMU rules. ${ }^{1}$ In defining a fiscal framework aimed at safeguarding the credibility of the single monetary authority and at avoiding monetary policy to be overburdened in its pursuit of price stability, the EU was confronted with several problems. ${ }^{2}$

First, while the intuition is clear (a sustainable policy must ultimately avoid insolvency), the analytical and operational definition of sustainability is not straightforward. Economic theory has proposed different conditions for sustainability (from a non ever-rising tax rate to an inter-temporal discounted budget constraint). The operational indications are not straightforward. For example, even if we agree that in order to be sustainable the debt-to-GDP ratio must be stable, we have no indication as to which stable level is sustainable. To assess the maximum sustainable debt level one should consider the interaction of public finance and the economy (and there is not an agreed upon theory on that). Moreover, difficulties arise also with regards to the definition of the variables to be used in the analysis (should gross or net debt be used? how should the deficit be measured?).

Second, the rules were to be applied to a group of countries, each retaining fiscal sovereignty. A general commitment to carry out sound fiscal policies was not sufficient. Monetary stability represents a public good to which all governments contribute by maintaining sustainable budget

1 The rationale for EMU rules is discussed, e.g., in Buti and Sapir (1998) and in Brunila, Buti and Franco (2002).

2 Balassone and Franco (2000a, 2001). 
positions. As with all public goods, there is an incentive for each government to exploit the benefits accruing from the discipline of others without contributing itself. This creates a double cost for the other governments: the free-rider's excessive indebtedness can put pressure on interest rates to rise. It can also result in bankruptcies requiring bail-outs.

Third, the deficit and debt positions of EU countries in the early 1990s were very different. Some countries were clearly in unsustainable fiscal positions, with high and rising debt and deficit ratios and large expected expenditure increases. In order to induce a sharp change in the budgetary policies of these countries, tight numerical parameters were required. Since it was politically difficult to differentiate the conditions set for accession to EMU from those envisaged to be a permanent feature of the Union's fiscal framework, ${ }^{3}$ the former substantially affected the latter.

When confronted with these difficulties, the EU adopted a pragmatic approach. The Treaty of Maastricht defines sustainability as non-violation of arbitrarily predetermined parametric standards, which are 3 and 60 per cent of GDP for deficit and debt respectively. ${ }^{4}$ The Treaty makes no distinction between current outlays and investment. ${ }^{5}$ The deficit ceiling is reminiscent of the constant deficit assumption analysed by Domar (1944). Apparently conscious of the partial equilibrium nature of Domar's results, the debt ceiling avoids convergence to high levels of debt.

The SGP later introduced a medium term target of a position "close to balance or in surplus" thus tightening the deficit rule while also trying to reconcile it with counter-cyclical fiscal policy. ${ }^{6}$ The equilibrium value of the debt ratio depends on the numerical definition of this position which, in turn, is to be determined so as to allow enough room for stabilisation policy while avoiding to breach the 3 per cent deficit threshold during cyclical downturns.

The implied policy stance may often be tighter than what is needed for sustainability by whatever definition. ${ }^{7}$ If EU countries stick to the close-to-balance guideline, they will converge to equilibrium debt levels much below the 60 per cent threshold. Some countries might even converge to negative debt levels. One may question whether a theory-based benchmark, if available, would have implied these results. No definition actually envisages the abolition of public debt.

3 This was due, inter alia, to the possibility of other countries joining EMU at a later stage. Moreover, it was clear that the reduction of debt to acceptable levels required long periods of fiscal restraint.

4 Article 121 requires "the sustainability of the government financial position" for a country's eligibility to EMU. Article 104 defines the criteria to evaluate sustainability by means of reference values for deficit and debt to GDP ratios. The economic rationale of the parameters has indeed been questioned, see Buiter et al. (1993) and Eichengreen and Von Hagen (1996) for a discussion.

5 However article 104 includes capital outlays among the relevant factors for the assessment of member states' budgetary positions.

6 Leeftink (2000) tests for the consistency of the two objectives, while Lindh and Ohlson (2000) doubt the capability of the Pact to ensure that budgetary policy reacts symmetrically to positive and negative cyclical developments.

7 See Pasinetti (1997), Kinnunen and Kuoppamaki (1998), Balassone and Monacelli (2000). Cronin and McCoy (2000) argue that the rules set in the SGP may prove too tight for countries with underdeveloped infrastructures. 
The SGP combines the traditional requirement to balance the budget with the call for letting the budget adapt to cyclical conditions. It also recognises the role of extraordinary finance. ${ }^{8}$

The definition of the debt and deficit indicators relevant for EMU's fiscal rules takes into account the need to ensure comparability of national statistics and to allow a regular surveillance process. Methodological choices were made with pragmatism. The sector of reference is general government, as defined in the European System of Accounts (ESA) under the responsibility of Eurostat. Debt and deficit are respectively defined as the total of gross general government liabilities at nominal (face) value and as the balance of non-financial transactions (as defined in the ESA) of general government. ${ }^{9}$

Reference to a common protocol is obviously helpful for international comparison. Using definitions in line with those adopted by Statistical Offices makes immediately available past data and allows to base forecasts on the most detailed databases. [The choice of a gross measure for debt also depends on data availability, since data on assets are not always available and their quality is often poor. However, these solutions come at a cost. The definitions adopted for debt and deficit are not consistent (i.e. the ESA95 deficit does not coincide with the change in debt). ${ }^{10}$ ]

2.2 Assessing fiscal sustainability in the EU. - The EMU fiscal framework does not make sustainability indicators unnecessary. Due to, inter alia, demographic changes, compliance over the short and medium term does not necessarily ensure compliance over the long term. There is a need for indicators highlighting prospective deviations and measuring their size and timing.

The issue of long-term sustainability has gradually gained importance in the assessment and design of fiscal policy. In a report on the co-ordination of economic policies to the European Council held in December 1999, the Ecofin noted the need for an explicit reference to the sustainability of public finances. The Ecofin called for a broadening of the issues covered by the Stability and Convergence programmes to medium and long-term sustainability problems. Subsequently, several European Councils highlighted the population ageing problem and, in particular, its implications for maintaining adequate and sustainable pensions. ${ }^{11}$ In particular, in March 2001 the European Council held in Stockholm established a three-pronged strategy to tackle the budgetary implications of ageing population. The strategy envisages raising employment rates (especially amongst women and older workers), reducing public debt and reforming pensions and health-care systems.

8 The cyclical events to be considered extraordinary are explicitly defined.

9 Financial instruments to be considered and accounting criteria to be used are also specified in the ESA. For an extensive analysis see Mink and Rodriguez-Vives (2004). Some problematic aspects are examined in Balassone et al. (2004).

10 In particular, with the adoption of the 1995 version of the ESA, deficit figures are based on accrual accounting.

11 The European Council held in Lisbon in March 2000 stressed the need to study the future evolution of social protection from a long-term perspective, with particular attention to the sustainability of pensions. 
The Council also agreed that long-term fiscal sustainability should be regularly reviewed. The review would be done under the Broad economic policy guidelines and in the Stability and Convergence programmes presented each year by Member States. This decision extended the framework of the EU multilateral surveillance and introduced a specific commitment for the Commission to examine the long-term sustainability of public finances.

In view of the lack of a consensus on the definition of sustainability of public finances, in its assessments of the Stability and Convergence programmes, the European Commission follows a pragmatic approach. It addresses three policy questions: (i) Given the projected budgetary implications of population ageing, will the budgetary requirements of the Maastricht Treaty be respected on the basis of current policies? (ii) Are the medium-term budgetary targets outlined in the programmes compatible with an improvement of the sustainability of public finances? (iii) What are the main policy challenges facing Member States and what reforms should be envisaged?

In November 2002, in its Communication on Strengthening the coordination of budgetary policies, the European Commission suggested that sustainability concerns should be explicitly taken into account when assessing the budgetary positions of Member States under the SGP. To this end, greater weight should be attached to government debt ratios in the budgetary surveillance process; more specifically, the debt criterion set by the Treaty of Maastricht should be made operational. ${ }^{12}$ In addition, the assessment of the sustainability of public finances - as part of the Stability and Convergence programmes - should be upgraded, with firm policy conclusions as to whether the budgetary policies are ambitious enough to meet the challenge posed by ageing populations.

In its most recent contribution to the debate on strengthening the implementation of the SGP ${ }^{13}$ the Commission also notes that in defining the required debt reduction it is necessary to take into account the need to ensure prudent debt ratios before the impact of ageing takes fully place. Moreover, the Commission stresses that a better knowledge of the factors influencing long-term sustainability of public finances such as pension and contingent liabilities ${ }^{14}$ and assets is required. Further deepening the comprehension of these developments would help to integrate them better into the fiscal framework.

There are several ways in which more attention can be placed on the factors that may influence the medium and long-term dynamics of the debt. This paper explores two main possibilities: the use of pension expenditure projections made at the EU level by each Member State and the use of pension liabilities.

12 This is done along the lines developed in European Commission (2004a) report.

13 European Commission (2004b).

14 A contingent liability can be defined as a public sector action that determines a cash expenditure only if and when a certain event takes place. 


\section{Pension expenditure projections in the European Union}

This section examines the pension expenditure projections available in EU countries, at both the national and the international level, their use in the EU fiscal framework and some problematic aspects concerning the quality and comparability of the projections. Some methodological aspects concerning long-term expenditure projections are examined in Annexes 1 and 2.

3.1 Pension expenditure projections in the European Union. - All EU countries have developed models for projecting pension spending. This is a relatively recent developments: till the mid-1990s the availability of projections in EU countries was very uneven and their quality was sometimes unsatisfactory. ${ }^{15}$ The development of better forecasting models has been boosted by the decision to start joint projection exercises at the EU level (see Box 1).

Projections are usually made for periods of 30 to 50 years, although occasionally they extend to 75 years. Trends in expenditure items are generally evaluated in terms of their incidence on GDP or in terms of some synthetic indicator (as, in the case of forecasts of pension outlays, the equilibrium contributory rate). National projections primarily cover first pillar pension schemes, including private and public sector employees and self-employed workers. A full coverage appears only in a subset of EU countries (EPC, 2003). ${ }^{16}$ Belgium, Denmark, Finland, Ireland and Sweden have in their projections a full coverage of all social benefits, both in cash and in kind. This allows them to have a broad picture of the impact of ageing on the expenditure side of public finance.

In most EU countries national long-term projections are regularly updated to take into account changes in legislation, in the economic context and in the demographic scenario. In Denmark, Sweden and the UK projections are updated more than once a year; in Belgium, Germany and Italy once a year. ${ }^{17}$ Updates are less frequent in Austria (3 years), Ireland ( 2 years) and in the Netherlands (4 years). Irregular updating is being done in Finland, France and Portugal. In Greece a National Actuary Authority has been recently established and it is in charge of producing long-term projections on a regular basis.

15 Franco and Munzi (1996) review the projections available at the national level in the 15 EU Member States in the mid-1990s...

16 Austria, the Netherlands, Spain and the UK do not project at least some part of the pension system in their national exercises.

17 In Germany this applies to projections performed for the general statutory pension scheme, whereas projections for the civil servant's pension scheme are updated once in every legislative period. 


\section{Pension expenditure forecasting exercises conducted by national institutions in the EU}

Over the past decade, all EU countries have developed models for forecasting the financial situation of public pension systems. A review of the forecasts on pension outlays for the period 1995-2030 carried out by public institutions in the fifteen EU member countries in the early 1990s found an average increase in the ratio of pension spending to GDP ranging between 3 and 4 points, i.e. about a tenth of a point per year (Franco and Munzi, 1996). The exercises pointed to a significant increase in spending not only in many countries that had not yet reformed their pension systems (Belgium, Denmark, Ireland, Luxembourg and the Netherlands) but also in some countries that had already enacted major reforms (Finland, France and Germany). Relatively limited increases in spending were expected in Italy, Portugal, Spain, Sweden and the United Kingdom. In many countries the ratio of pension expenditure to GDP in 2030 was projected to be between 15 and 20 per cent.

There is a tendency towards a more regular release of projections. In the United Kingdom, since 1975 the Government Actuary's Department has revised the long-term forecasts of the National Insurance Scheme every five years. One section of each forecasting report describes the changes from the previous set of projections. In Germany, the Federal Government releases 15-year projections every year. The need for regular forecasts (every five years) was acknowledged in Ireland in the 1993 report of the National Pensions Board and in Spain by the Toledo Pact of 1995. In Italy, forecasting activity has found increasing legislative support. A law in 1988 established that technical reports on draft bills concerning pensions must include projections covering at least ten years. In 1995 it was further decided that starting in 1998 the annual Economic and Financial Planning Document must have a special section projecting pension spending for the subsequent decade.

In the last few years, a number of countries produced new estimates of pension spending trends. In some cases they are aimed at simply evaluating the future pension expenditure on the basis of existing conditions (Blanco Moreno et al., 2000); in others, they are directed to the enactment of further reforms (Charpin, 1999). In still others, they are intended to help determine the best policy for dealing with the problems posed by population ageing.

In the Netherlands, the Bureau of Economic Policy Analysis (2000) forecasts pension spending within a projection of the entire government budget in which population ageing significantly affects health and welfare spending and some revenue items as well. The report seeks to assess the conditions under which the public finances may prove sustainable in the long term and considers possible actions on budget policy, the labour market, the pension system and health care. The various solutions are weighed both in terms of efficient resource allocation and in terms of intergenerational redistribution.

The Ministry of Economic Affairs of Denmark (2000) forecasts public pension outlays as part of an exercise designed principally to project the total income of retirees, including private retirement plans and investment income. The report estimates the composition of these incomes and the income replacement rate vis-à-vis earnings from labour, for different population deciles in 1996 and 2045. It examines the relation between pension system and labour market, specifically for people aged 60 to 66 and it evaluates the overall prospects for the public finances, also considering the implications of alternative economic policy scenarios for the various generations. 
Across countries there are also differences concerning forecasters. In particular, the forecasting process may involve officially or unofficially several actors: social partners, independent experts, social security institutions and ad hoc public bodies (committees, working groups, etc.) made by officials from the public administration, external experts, social partners and representatives of the national Parliament. ${ }^{18}$

In EU countries long-term projections are used to set up budgetary medium-term targets, ${ }^{19}$ to plan major reforms with an impact on budgetary positions, to project the debt profile and to assess the long-term sustainability of public finances.

The assessment of long-term sustainability of public finances is conducted primary by Ministries of Finance or Economy but there are cases where the Social or Labour Ministries or other public institutions are involved. A key issue is the definition of long-term sustainability of public finances. It can refer to debt dynamics or to a budget balance position. ${ }^{20}$

18 In Germany, each annual update of pension expenditure projections is object of consultation: it is usually organised a workshop on methodology and main assumptions that involve the Pension Insurance institutions and the Federal Ministry of Health and Social Affairs. Other institutions are also consulted and at the end of the process a special advisory board assesses the results and forwards the assessment to the Federal Parliament. In Austria, there is a consultant body to the federal government composed of ministry representatives, social partners and researchers that discusses projections and presents a report to the government. In Portugal, an inter-ministerial working group on ageing discusses technical aspects of the projections. Ad hoc groups are established in the Irish Finance Ministry (the Long-Term Issues Group) and in Belgium (Comitè d'etudes sur le vieillissement). In France, a body attached to the Prime Minister's Office co-ordinates the consultation with many different actors (social partners, Parliament, Ministry of Finance, etc.) In most cases the final responsibility for producing long-term projections is within a governmental body, mainly the Treasury or Finance Ministry or the Labour or Social Affairs Ministry.

19 This is the case for Belgium, Denmark, Finland, the Netherlands and Sweden. In the Netherlands, for instance, since long-term projections indicate that the elimination of public debt within this generation would allow to cover part of the costs of ageing through interest savings, the medium-term budgetary target is then defined to achieve this result. In Sweden and Denmark projections have been used in setting the medium-term target of 2\% of GDP surplus. Belgium and Finland fix medium-term targets in order to be consistent with a projection where the budgetary path ensures long-term sustainability, taking into account the likely impact of ageing.

20 In the Netherlands and Denmark long-term sustainability is evaluated on the debt basis: public finances are considered sustainable if debt is not on an "explosive path", implying a constant debt to GDP ratio over the longterm. Other countries, for instance Sweden, refer to the debt to GDP ratio ceiling established by the Maastricht Treaty considering sustainable only debt path that does not exceed the reference value over the entire projection horizon. In Italy two ways to assess long-term sustainability of public finances are used: the first one refers to a debt reduction towards $60 \%$ of GDP; the second one looks at the impact of different debt structure scenarios on the cost of debt and on real GDP growth rates and this analysis is then used to project the evolution of the debt to GDP ratio in a long-term perspective. Belgium and Austria refer more explicitly to the necessity of maintaining each year a budget position which is balanced or in surplus over the cycle. In the United Kingdom sustainability is defined as meeting the government's sustainable investment rule, which says that net debt should remain below $40 \%$ of GDP over the economic cycle. In addition the United Kingdom presents other indicators such as fiscal gaps and the intertemporal budget gaps to provide further information on sustainability. In Germany, the indicators refer more directly to the pension system: for the statutory pension scheme long-term sustainability has been defined by setting specific reference values for the maximum rate of contribution as well as for the standard benchmark of the replacement rate; for the civil servants' pension scheme long-term sustainability is assessed by looking at the pension to tax ratio and the pension to GDP ratio for this particular type of pension expenditure. 
Projections typically include a baseline scenario representing a continuation of current policies, particularly with respect to social insurance legislation (in terms of eligibility conditions and the amount of the benefits) and alternative scenarios for relevant economic and demographic variables (low and high population scenarios, lower and higher productivity growth scenarios, lower unemployment rate scenario, lower and higher interest rates scenarios). These alternative exercises may also seek to evaluate the impact of specific policy adjustments or of alternative policy assumptions (e.g., changing the age of pension eligibility). ${ }^{21}$

Finally, projections are usually deterministic, implying that even when accompanied by stress tests, they confer no sense of the likelihood of any specific scenario taken into consideration. Sometimes, one observes a pairing of assumptions that might yield the most optimistic or pessimistic case but that may be unlikely to occur together.

The issue of long-term term fiscal trends has been gaining importance at the EU level since the late 1990s. After some technical work carried out by the Commission, ${ }^{22}$ in 1999 a technical working group (the Ageing Working Group - AGW) was set up to examine the economic and budgetary implications of ageing populations and provide expenditure projections (see Box 2). ${ }^{23}$ The AWG provides projections of public expenditure on pensions, on health and long-term care and a number of indicators of long-term fiscal sustainability. ${ }^{24}$ The projections involve the use of the forecasting models developed by national authorities but are based on common demographic forecasts and assumptions on key economic parameters such as labour market developments, productivity growth and real interest rates. ${ }^{25}$ The projection exercises increase the comparability of national forecasts, though leaving responsibility for the projections to the national authorities, which have the best institutional and statistical knowledge.

The AWG exercises refer to a current policy scenario, which does not necessarily represent what Member States consider to be the most likely scenario, but rather the consensus reached in the group as to what would constitute a prudent and reasonable starting point. The AWG estimates are based on the demographic projections prepared by Eurostat on the basis of assumptions regarding fertility

21 For a brief description of the models and scenario adopted by EU countries, see the table in the Annex 2.

22 Franco and Munzi (1996 and 1997).

23 The Ageing Working Group was set up by the Economic Policy Committee (EPC) of the EU. The group includes experts from national administrations, the European Commission, the European Central Bank and the OECD.

24 Economic Policy Committee (2000, 2001 and 2003). 


\section{Co-ordinated exercises promoted by the European Commission}

In Economic Policy Committee (2000) the pension expenditure-to-GDP ratio is predicted to rise in all EU countries but the United Kingdom over the coming decades. In some countries, the rise is significant. Expenditure peaks are reached at different times. In particular, in the majority of countries the effects of ageing will add 3 to 5 percentage points of GDP to pension expenditure: Austria (3.1 per cent by 2030), Belgium (3.7 per cent, peaking in 2040), Denmark (4.5 per cent, by 2030), Finland (4.7 per cent, by 2040), France (3.9 per cent, by 2030), Germany ( 4.3 per cent, by 2050 or after), and Ireland (4.4 per cent, by 2050 of after). In some countries the upward pressure is even higher: the Netherlands (6.2 per cent, by 2040), Spain (8.3 per cent, by 2050), and Portugal (6.2 per cent, by 2030). Moreover, the results have been decomposed according to the four explanatory factors driving the projected changes in pension spending: the population ageing effect, which measures the changes in the ratio of persons aged 55 over the population aged 15 to 54; the employment effect, which indicates the changes in the share of population in working age (15 to 64) that is employed; the eligibility effect, which measures the share of the population aged 55 and over that receive a pension; the benefit effect, which captures changes in the average pension relative to output per worker. Sensitivity tests were carried out to gauge the impact of changes in various parameters, i.e. population, participation rate, employment rate, productivity rate and interest rate. A policy simulation based upon the successful implementation of the Lisbon strategy was also carried out compared with the "current policy scenario".

Economic Policy Committee (2001) builds upon the previous report: for some countries the data provided have been supplemented and in some cases updated to incorporate the impact of recent reforms. ${ }^{(1)}$ Notwithstanding these changes, Economic Policy Committee (2001) confirms the previous results. The projections show that for the EU as a whole, public pension spending is projected to peak in 2040 at 13.6 per cent of GDP from 10.4 per cent in 2000. It should be noted that the projection exercise has only considered pension expenditures and not revenues to pension systems, although some Member States did report data.

According to Economic Policy Committee (2003), the ageing populations will lead to an increase in public spending (including not only pensions but also other age related items) of between 3 and 7 percentage points of GDP by 2050 if no corrective action is taken (Table 1). Most of the increase will derive from pensions, health and long-term care spending, whereas savings stemming from education and unemployment benefits will be limited. In particular, public spending on pensions is projected to increase by between 3 and 5 percentage points of GDP, largely driven by the increase in the old-age dependency ratios. Reforms in the 1990s, especially the indexation of entitlements to prices and extension of assessment periods, appear to have mitigated the expenditure increases in some countries. Demographic changes would lead to a rise in public spending on health and long-term care by between 1.5 and 4 percentage points of GDP up to 2050 . However, there are upside and downside risks to the projections results as the impact of non-demographic factors was not explicitly modelled. Public expenditure in education is expected to decline in the next 50 years, but significant savings are projected only in some countries. Using the labour force assumptions, unemployment benefit spending will show very modest decreases in most Member States.

(1) For a summary description of recent reforms, see European Commission (2000a), EPC (2003), and Franco and Marino (2003). The reforms regarded indexing (Germany and Italy), the reference period for calculating the pension award (Spain), the retirement age for women (Austria, Belgium, Germany and the United Kingdom) and the requirements for early retirement eligibility (Austria, Denmark, Germany and Italy). 
Table 1

\section{Projections for public spending on pensions, health, long-term care, education and unemployment benefits ${ }^{(1)}$}

(as a percentage of GDP)

\begin{tabular}{|l|c|c|c|c|c|c|c|c||}
\hline & $\mathbf{2 0 0 0}$ & $\mathbf{2 0 0 5}$ & $\mathbf{2 0 1 0}$ & $\mathbf{2 0 2 0}$ & $\mathbf{2 0 3 0}$ & $\mathbf{2 0 4 0}$ & $\mathbf{2 0 5 0}$ & Change \\
\cline { 2 - 9 } Belgium & 23.9 & 22.5 & 22.9 & 24.1 & 27.0 & 27.9 & 27.5 & 3.7 \\
Denmark & 28.5 & 29.1 & 31.0 & 32.7 & 34.3 & 34.7 & 33.9 & 5.4 \\
Germany & 24.0 & 23.7 & 23.4 & 24.9 & 28.4 & 29.9 & 30.2 & 6.1 \\
Greece & 21.8 & 21.1 & 21.1 & 24.0 & 28.8 & 33.5 & 34.8 & 13.0 \\
Spain & 21.3 & 19.3 & 19.1 & 20.2 & 23.0 & 26.9 & 28.7 & 7.4 \\
France & 26.5 & 26.3 & 26.9 & 29.3 & 30.6 & 30.6 & 30.5 & 4.0 \\
Ireland & 10.1 & 9.6 & 9.7 & 11.2 & 11.9 & 12.2 & 13.2 & 3.1 \\
Italy & 24.2 & 24.4 & 24.5 & 25.5 & 26.6 & 27.1 & 25.8 & 1.6 \\
Luxembourg & 7.6 & 7.4 & 7.9 & 8.6 & 9.5 & 9.8 & 9.5 & 1.9 \\
Netherlands & 21.4 & 21.8 & 23.1 & 25.5 & 28.3 & 30.4 & 30.3 & 8.9 \\
Austria & 26.9 & 27.1 & 27.4 & 28.5 & 31.3 & 32.1 & 31.1 & 4.2 \\
Portugal & 21.5 & 22.0 & 23.0 & 24.6 & 24.9 & 25.5 & 25.1 & 3.5 \\
Finland & 25.3 & 24.8 & 25.5 & 27.1 & 30.2 & 32.0 & 31.8 & 6.5 \\
Sweden & 27.0 & 26.8 & 27.2 & 27.8 & 30.0 & 31.0 & 30.6 & 3.6 \\
UK & 17.4 & 17.5 & 17.3 & 17.0 & 18.0 & 17.3 & 18.0 & 0.6 \\
EU 15 & 21.8 & 21.6 & 22.0 & 23.4 & 25.5 & 26.7 & 26.7 & 4.9 \\
\hline \hline
\end{tabular}

Source: EPC (2003).

(1) The table brings together the results of the AWG's "current policy scenario" projections for spending on pensions, health and long-term care using the per capita GDP costs rule completed in 2001, with the projections for public expenditure on education and unemployment benefits completed in 2003. Pension spending forecasts for Austria, France, Germany, Spain and Portugal take into account the effects of the recent pension reforms and the revised population projections.

rates, life expectancy and migration. ${ }^{26}$ Long-run projections for social expenditures are heavily influenced also by assumptions on labour market developments and other macroeconomic variables. $^{27}$

26 In Eurostat baseline scenario fertility rates are projected to converge upward to an average of 1.7 for the EU by 2050 (the average EU fertility rate in 2000 stood at 1.5), with most of the increase occurring in the coming two decades. Regarding migration flows, it is assumed a net inward migration to EU countries of about 640,000 people per year (about 0.2 per cent of the total population). Life expectancy is projected to steadily increase over the projection period: for men it is projected to rise from 75 years in 2000 to 80 years by 2050; for women, from 81 to 85.

27 The AWG in Economic Policy Committee (2000 and 2001) used the same assumptions agreed in the OECD projection exercise. Labour force participation rates up to 2010 are based on projections by the International 
3.2 From expenditure projections to sustainability analysis. - The expenditure projections provided by the AWG are used for building up sustainability indicators which provide a quantitative estimate of the budgetary adjustments required for a Member State to ensure sustainable public finances and compliance with the SGP. The starting point is either given by the general government today accounts or by the end-period forecasts provided for in the Stability and Convergence programmes. The initial non-pension primary expenditure and revenue are kept constant over time while the pension expenditure developments are projected on the basis of a set of assumptions on demographics, labour participation rates and other relevant variables. Given certain assumption concerning GDP growth and interest rates, the increase in the spending ratio is used to project the primary balance and debt dynamics (see Box 3).

These computations are then used for building up tax gaps (also called "sustainability gaps"), i.e. the difference between the current tax ratio and the constant ratio that would be needed over the projection period to achieve a pre-determined budgetary target at a specified date in the future (for correcting the projected values which take into account the pension-expenditure projections). Since the choice of both the targeted debt ratio and the length of the projection period is arbitrary, the European Commission calculates three different tax gaps, covering a range of definitions of sustainability used in the literature:

- the first one measures the difference between the current and constant tax ratio required to reach the same debt level in 2050 that would result from a balanced budget position over the entire projection period (known as T-1);

- the second one recognises that the requirement of debt levels converging to zero implied by the first tax gap is an overly strict definition to ensure sustainability of public finances and so it measures the difference between the current and constant tax ratio required to reach a debt level of 40 per cent of GDP in 2050 (known as T-2);

- the third one draws from the economic literature based on the present value budget constraint. It indicates the change in tax revenue as a share of GDP that would guarantee the respect of the intertemporal budget constraint of the government. In this case there is no target for the debt level but it will converge towards a relatively low level. Furthermore, there is no cut-off date and this requires the assumption that age-related expenditures remain constant as a ratio to GDP at the projected level in 2050 (known as T-3).

Labour Organisation (ILO, 1997). Thereafter, labour force participation rates are constant for men and rising for women (the latter rates reach in 2050 levels of 5 to 10 points lower than those assumed for men). Unemployment rates are assumed to fall to their structural level by 2005, as defined by the OECD, and to stay constant thereafter. For the EU, this results in unemployment falling to 8 per cent. The AWG agreed that labour productivity growth should converge towards an annual rate level of 1.75 per cent by 2030 , although some leeway for higher rates is provided for catching-up countries. 


\section{The European Commission assessments of sustainability of public finances}

On the basis of the updates of the stability and convergence programmes submitted by EU Member States at the end of 2001 and the beginning of 2002, the European Commission found risks of budgetary imbalances inconsistent with the Stability and Growth Pact (SGP) in seven countries (Austria, France, Germany, Greece, Ireland, Spain and Portugal). Other three countries (Finland, the Netherlands and the United Kingdom) did not pass the stress test assuming a one per cent of GDP deviation from their medium-term budget target in 2005 and carried over up to 2050.

In the updates of the stability and convergence programmes submitted between the end of 2002 and the first half of 2003, twelve countries presented long-run projections conducted by national institutions (European Commission, 2003). For four countries these projections were significantly different from the EPC projections. In all these cases, the updates indicated more favourable developments than those obtained by the EPC. Even assuming that all countries achieve the budget targets set for 2006, the European Commission found that there is a risk that public finances are not sustainable in six countries (Austria, France, Germany, Greece, Italy and Portugal) and in the EU as a whole. The Commission therefore asked for further policy measures.

The debt developments would follow a U-shaped curve in most countries: the level would initially decline given the favourable starting budgetary positions and would worsen when the impact of ageing takes hold. In most countries the largest increase in the debt will occur between 2020 and 2030. The European Commission stresses that the risk of non-sustainable public finances increases in all countries that do not achieve budget position close to balance or in surplus. This is most relevant for countries with high debt level (France, Germany, Italy and Portugal). Finally, the tax gap indicators reveal that additional permanent budgetary adjustments between 1 and 2 percentage points of GDP are needed in those EU countries where sustainability of public finance is a concern.

On the basis of the 2003 updates of the stability and convergence programmes, EPC (2003) estimates that even assuming that all EU countries achieve their medium term budgetary targets there is a risk of unsustainable public finances in at least one third of them. Debt developments for most countries follow a U-shaped pattern: in the coming twenty or twenty-five years debt levels are projected to decrease as a consequence of the maintaining of balanced budget positions but this trend would start to reverse once the budgetary impact of ageing starts to prevail, with the largest increase in most countries expected between 2030 and 2050.

The risk of unsustainable public finances increases considerably if countries do not reach a budget position of close to balance or in surplus. This is shown comparing the projected debt levels under the "programme scenario" with the "2003 budgetary position" scenario. This is particularly true for the six euro-area countries with highest underlying cyclically adjusted deficits in 2003 (France, Germany, Greece, Italy, the Netherlands and Portugal). The sustainability gap under the "programme scenario" indicates that an additional permanent budgetary adjustment of between 1.5 and 2.5 percentage points of GDP is needed in countries where the sustainability of public finances is a concern. 
These indicators are calculated for two scenarios: the programme scenario and "current year" scenario, where the starting point is the current budget position. The latter scenario demonstrates the long-term impact on debt developments, and consequently on the sustainability of public finances, of a failure to achieve the 'close to balance or in surplus' requirement of the SGP for those countries still in deficit, in accordance with the timetable set down in their stability or convergence programmes.

The EPC has a mandate to deliver a new set of common budgetary projections by mid-2005 for all 25 EU countries. A number of guiding principles for the design and execution of the projection exercise has been agreed upon in order for the AWG to fulfil this ambitious mandate: i) an appropriate balance between the need for simplicity and economic relevance has to be found in choosing the methodology to be used to forecast age-related public expenditure items; ii) in order to ensure comparability, adjustments for individual country specific circumstances should be kept to a minimum with the principle of equal treatment for all countries being respected; iii) the assumptions underlying the expenditure projections should be consistent with each other (i.e., the assumptions on participation rates of women need to be consistent with developments of the fertility rates); iv) the assumptions underlying the projections should be adopted on a prudent basis, so as to avoid the risk of underestimating the possibility of serious economic and budgetary challenges emerging in the long run; v) all key inputs and assumptions used for the projections should be clearly specified, along with the projection models.

The coming exercise will aim at providing policy makers with a better assessment of the sources of risks to public finances in the long-run. The exercise will involve sensitivity tests. Where possible, probabilities will be attached to alternative scenarios. To this end, the following steps have been agreed by the AWG.

- First, projections should cover the period up to 2070 , because otherwise it would not be sufficient to cover the working lives of all persons alive today and thus would not cover the pension entitlements of younger age cohorts who have recently, or will shortly, enter the labour force. Moreover, in countries where the baby-boom effect occurred later, the population size and structure will not have stabilised around a new equilibrium level by 2050 .

- Second, the new projections would be based on a revised set of population projections prepared by Eurostat. Appropriate sensitivity tests for different scenarios on population developments would be carried out.

- Third, the age-related expenditure projections would continue to be made using national models and agreed, but more tightly specified, assumptions on key economic parameters.

- Fourth, the same underlying assumptions on economic parameters (participation and employment rates, productivity growth, real interest rates) will be used in all the projection 
exercises. To this end, a discussion will first take place in the AWG on each economic assumption in order to take into account country-specific situations. Thereafter, the European Commission will propose the underlying assumptions to be used. Final decisions on the assumption to be used are to be made subject to the agreement of the Chairman of the AWG and provided the principle of equal treatment across countries is respected at all times.

- Fifth, national authorities will report projection results in a common reporting format to be developed by the Commission.

The AWG plans to produce policy simulations regarding migration, ${ }^{28}$ pension reforms (running simulations on the impact of changes in indexation mechanisms, changes in effective retirement ages and adjusting pension entitlements to life expectancy at retirement), health care and long-term care (controlling costs in this field is likely to play an important role for the overall budgetary performance), labour market developments and the Lisbon employment targets.

3.3 Problems with EU pension projections. - The joint projections exercises carried out by the AWG represent an important step forward. First, they make sure that all EU countries regularly produce pension expenditure projections. Second, the need to regularly update the projections, to discuss them in a multinational context and to respect some agreed guidelines provides an incentive to produce unbiased forecasts. Third, the common demographic and economic assumptions increase the comparability of outcomes.

However, there are still a number of problems. Differences in modelling approaches, coverage of projections and the significant margin left to national authorities to fix underlying economic assumptions make the results not comparable in a strict sense. The information made public is often not sufficient for a full assessment of the forecasting exercises and for conducting alternative exercises. Moreover, the institutions assigned to make the projections are often those responsible for designing social policy, which may affect both the availability and the substance of the forecasts, and the information.

28 The simulations would assess the contribution of inward migration flows to offsetting some of the economic and budgetary implications of ageing populations. 


\section{The role of pension liabilities}

This section explores the potential role of PAYG pension liabilities in the EU fiscal framework. A radical solution would imply assimilating pension liabilities to conventional public debt. This would also require a change in the computation of the budget balance: social contributions would be considered as loans to public pension schemes and pension spending as loan repayments.

4.1 How to define pension liabilities. - Any PAYG pension scheme gives rise to unfunded liabilities. ${ }^{29}$ Within these schemes each generation provides the resources for paying the pensions to the previous generation and later receives pensions financed by younger workers. Therefore, at any point in time there exist a number of retired citizens who are entitled to a pension for the remaining part of their life (and sometimes also of the life of their widowed spouse) and a number of working citizens who can claim a right to a pension either in the near or in the distant future.

There exist three main definitions of pension liabilities (Castellino, 1985; see also Box 4).

1. Accrued-to-date liabilities: these represent the present value of pensions to be paid in the future on the basis of accrued rights; neither the future contributions of existing workers, nor the accrual of new rights by them are considered.

2. Current workers and pensioners' net liabilities: in this case it is assumed that pension schemes continue their "existence until the last contributor dies, while no new entrants are allowed"; ${ }^{30}$ both the future contributions of existing members and their new rights are therefore allowed for under current rules. ${ }^{31}$

3. Open-system net liabilities: these also include the present value of contributions and pensions of new workers under current rules; the range of options extends from including only children not yet in the labour force to an infinite perspective.

The three pension liabilities definitions share the pensioners' liabilities component, but differ as to the workers' component. More specifically, the first definition includes only the present value of accrued-to-date benefits of present workers. The second one also refers to the future benefits of present workers and to their future contributions. The last definition also considers the benefits and contributions of people who have not yet entered the labour market.

29 It is "a pension finance arrangement whereby current liabilities are met from current contributions, and no fund is accumulated in advance to meet future needs" (Dilnot et al. 1994, p. 212). The debt arises with the creation of the PAYG pension scheme, when a generation of elderly citizens receives a pension without having paid any previous contribution or when the contributions do not guarantee an adequate pension.

30 Van den Noord and Herd (1993).

31 This definition corresponds to the concept of "net social security wealth" developed by Feldstein (1974) and frequently referred to in the debate concerning the effects of social security on saving decisions. 


\section{The valuation of pension liabilities}

This box formalises in an extremely simplified way the key equations for representing the three pension liabilities definitions reported above. Disability pensions and survivor pension are not accounted for. It has to be noted that the equations which follow should be considered as applying to each single pension scheme existing in a country, since pension schemes usually have different features and rules (as to age, sex, wage, contributory periods, etc.). The differentiation of rules for males and females is also not considered.

The valuation of accrued-to-date liabilities. - Accrued-to-date liabilities $(L)$ represent the present value of pensions to be paid in the future on the basis of accrued rights. They include both present pensioners liabilities $(L P)$ and present workers ones $(L W)$.

In principle, the pension liabilities pertaining to each pensioner of age $a$ are as follows:

$$
\mathrm{LP}_{\mathrm{a}}=\sum_{\mathrm{i}=\mathrm{a}}^{\infty} \frac{\mathrm{B}_{\mathrm{i}} \mathrm{S}_{\mathrm{i}}}{(1+\mathrm{r})^{\mathrm{i}-\mathrm{a}}}
$$

where $B_{i}$ represents his pension in year $i, S_{i}$ represents his probability to be alive in year $i, r$ is the discount rate. By assuming that the pension increases at a constant rate $(p)$ and given his present pension $\left(B_{a}\right)$ one obtains:

$$
\operatorname{LP}_{a}=B_{a} \sum_{i=a}^{\infty} S_{i}\left(\frac{1+p}{1+r}\right)^{i-a}
$$

The total present value of pensions existing in year is the following:

$$
\mathrm{LP}(\mathrm{t})=\sum_{\mathrm{J}=\underline{\mathrm{J}}}^{\infty} \mathrm{N}_{\mathrm{j}}^{\mathrm{P}} \mathrm{B}_{\mathrm{j}}^{\mathrm{p}} \sum_{\mathrm{i}=\mathrm{t}}^{\infty} \mathrm{S}_{\mathrm{i}, \mathrm{j}}^{\mathrm{P}}\left(\frac{1+\mathrm{p}}{1+\mathrm{r}}\right)^{\mathrm{i}-\mathrm{t}}
$$

where $j$ is the minimum pension age, $N_{j}^{p}$ is the number of pensions paid to pensioners of age $j$ in year $t, B_{j}$ is the average pension paid to pensioners of age $j$ in year $t$ and $S_{i, j}^{P}$ is the probability to be alive in year $i$ for pensioners of age $j$ in year $t$.

Along the same lines, the present value of workers' liabilities $(L W)$ can be computed.

$$
\operatorname{LW} 1(t)=\sum_{J=\underline{J}}^{\infty} N_{j}^{w}\left[B_{j}^{w} \sum_{i=t}^{\infty} Q_{i, j} S_{i, j}^{w}\left(\frac{1+p}{1+r}\right)^{i-t}\right]
$$

where $N^{w} j$ is the number of workers of age $j$ in year $t, B^{w} j$ is the average pension paid at retirement to workers of age $j$ in year $t$ computed on the basis of contributions already paid, $Q_{i, j}$ is the probability of receiving a pension at $\mathrm{t}$ for workers of age $\mathrm{j}$ in year $\mathrm{t}, S^{w}{ }_{i, j}$ is the probability to be alive in year $i$ for a worker of age $j$ in year $t$. 
The valuation of current workers and pensioners' net liabilities. - These represent accrued-to-date liabilities of workers and pensioners plus the present value of the rights present workers will acquire in the future net of future contribution of present workers.

While accrued pensioners liabilities are as before, the workers component also takes into account the present value of the rights that present workers will acquired in the future (WFB, workers' future benefits) net of the future contribution of present workers (WFC, workers' future contributions):

$$
\begin{aligned}
\operatorname{LW} 2(t) & =\operatorname{LW} 1(t)+\operatorname{WFB}(t)-\operatorname{WFC}(t)= \\
& =\operatorname{LW} 1(t)+\sum_{J=\underline{J}}^{\infty} N_{j}^{w}\left[B F_{j}^{w} \sum_{i=t}^{\infty} Q_{i, j} S_{i, j}^{w}\left(\frac{1+p}{1+r}\right)^{i-t}-C \sum_{i=t}^{\infty} R_{i, j} Y_{i, j}\left(\frac{1+p}{1+r}\right)^{i-t}\right]
\end{aligned}
$$

where $B F^{w}{ }_{j}$ is the average pension paid at retirement to workers of age $j$ in year $t$ computed on the basis of contributions to be paid in the future, $C$ is the contributory rate on labour income, $R_{i, j}$ is the probability of working in year i for workers of age $j$ in year $t$ and $Y_{i, j}$ is the labour income in year $i$ of a worker of age $j$ in year $t$.

The valuation of open-system net liabilities. - These include the present value of accrued and future rights of present workers and pensioners and the present value of pensions of new workers net of the present value of their future contributions.

While accrued pensioners liabilities and the net liabilities concerning present workers is as in the second definition of liabilities, one has also to consider the present value of the pensions of new workers (FWB, future workers' benefits) net of the present value of their future contributions (FWC, future workers' contributions). In case only children living at $t$ are considered:

$$
\operatorname{LWN}(\mathrm{t})=\mathrm{FWB}(\mathrm{t})-\mathrm{FWC}(\mathrm{t})=\sum_{\mathrm{J}=1}^{\bar{j}} \mathrm{~N}_{\mathrm{j}}^{\mathrm{C}}\left[\mathrm{B}_{\mathrm{j}}^{\mathrm{C}} \sum_{\mathrm{i}=\mathrm{t}}^{\infty} \mathrm{V}_{\mathrm{i}, \mathrm{j}} \mathrm{S}_{\mathrm{i}, \mathrm{j}}^{\mathrm{C}}\left(\frac{1+\mathrm{p}}{1+\mathrm{r}}\right)^{\mathrm{i}-\mathrm{t}}-\mathrm{C}^{\mathrm{C}} \sum_{\mathrm{i}=\mathrm{t}}^{\infty} \mathrm{K}_{\mathrm{i}, \mathrm{j}} \mathrm{Y}_{\mathrm{i}, \mathrm{j}}^{\mathrm{C}}\left(\frac{1+\mathrm{p}}{1+\mathrm{r}}\right)^{\mathrm{i}-\mathrm{t}}\right]
$$

where $N_{j}^{c}$ is the number of children of age $j$ in year $t, B_{j}^{c}$ is the average pension paid at retirement to children of age $j$ in year $t$ computed on the basis of full working life, $V_{i, j}$ is the probability of receiving a pension at $\mathrm{t}$ for children of age $j$ in year $t, S_{i, j}$ is the probability to be alive in year $i$ for a children of age $j$ in year $t, C^{c}$ is the contributory rate on labour income, $K_{i, j}$ is the probability of working in year i for children of age $j$ in year $t$ and $Y_{i, j}^{c}$ is the labour income in year $i$ of a children of age $j$ in year $t$.

So overall (actual and future) workers' liabilities under this definition are as follows:

$$
\mathrm{LW} 3(\mathrm{t})=\mathrm{LW} 2(\mathrm{t})+\mathrm{LWN}(\mathrm{t})=\mathrm{LW} 1(\mathrm{t})+[\mathrm{WFB}(\mathrm{t})-\mathrm{WFC}(\mathrm{t})]+[\mathrm{FWB}(\mathrm{t})-\mathrm{FWC}(\mathrm{t})]
$$


In other words, the last two definitions differ from the first one because they account also for new expected net rights (of a closed and of an open system, respectively). Therefore, these indicators can play a role in the assessment of the perspectives of pension schemes. Moreover, as new net pension rights can be estimated for different generations of born and unborn citizens, they can be useful in assessing the role of the public sector in determining the distribution of resources.

Estimates of pension liabilities require detailed information about the specific pension rules of each country and about the features of workers and pensioners with respect to age, sex, wage and contributory periods. These estimates depend on several assumptions on mortality rates, activity rates, wage and price trends. The discount rate of future contributions and benefits play also a crucial role. In addition, the last two definitions of pension liabilities require an assessment of the expected value of future contributions. ${ }^{32}$ In countries where pensions are included in the personal income tax base, liabilities should be net of the presumed taxes levied on them. ${ }^{33}$ This requires an estimate of the average tax rate on pensions. In this regard, it has to be considered that even assuming the stability of the present rate structure in real terms, ${ }^{34}$ the average tax rate on pensions is likely to change over time since the ratio of pension to other income may change. In countries where public pension schemes are fully or partially funded, liabilities should be computed net of pension fund assets.

4.2 Accrued liabilities. - Among the three definitions of pension liabilities, that of accrued-to-date liabilities is the only one that can be assimilated to conventional public debt.

Present pensioners and workers' liabilities and open-system liabilities include pension rights that are yet to accrue. Strictly speaking, these pension rights should not even be called liabilities, but potential liabilities. They cannot therefore be assimilated to conventional public debt, which is a backward looking statistic.

This section examines the indications provided by accrued liabilities and their possible role in the EU fiscal framework.

32 In the case of public pension schemes, this may raise some methodological problems. In some countries current pensions are fully financed by specific contributions to pension schemes. Future contributions can thus be assessed on the basis of present contribution rates. In other countries current pensions are also financed via other sources, such as general tax revenues and borrowing. In this latter case, if future contributions are assessed on the basis of the contribution rate to pension schemes, there is a tendency to overestimate liabilities. The overestimation would be particularly large for the countries relying mostly on general taxation. If, on the other hand, the relevant contributory ratio is assumed equal to the pension-to-expenditure ratio in the base year, there is a tendency to underestimate the imbalances of countries relying on borrowing. It would be better to try to assess future contributions on the basis of the present contributory rate to pension schemes plus present recourse to general taxation. In other words, present recourse to borrowing should be excluded from estimates of future contributions. However, also this method would involve some arbitrary assumptions.

33 No such adjustment is necessary for conventional public debt, since no tax is levied on public bonds when they are refunded.

34 Tax rates are adjusted to income changes in order to keep the tax to income ratio constant. 
4.2.1 Accrued liabilities and the sustainability of PAYG schemes. - The information that pension liabilities provide can be better understood by considering two stylised cases: the first takes a macro perspective; the second case takes a micro perspective and highlights the effects of demographic changes. The former is considered in what follows; the latter is analysed in Box 5, where also a numerical example is considered.

Let us consider a steady state situation where the ratio of any expenditure to GDP is constant over time. Suppose there are two countries (A and B) in which, ceteris paribus, PAYG pension spending is respectively $X$ and $a X$ per cent of GDP (where $a>1$ ). Overall public spending is the same in both countries because country A devotes $(a-1) X$ per cent of GDP more spending than country B to nonpension spending programmes. Country A and country B devote on a permanent basis revenues amounting respectively to $X$ and $a X$ of GDP to their PAYG schemes. In the steady state, the ratio of accrued-to-date liabilities to GDP is given by the discounted value of the ratios of future pension spending to GDP and so the latter is proportional to pension spending as a share of GDP. This means that, notwithstanding the same underlying sustainability circumstances, country B pension liabilities are $a$ times those of country A.

Therefore, the size of unfunded pension liabilities does not indicate that PAYG systems are unbalanced or will be unbalanced in the future. The matter should be rather judged in terms of the efficiency of PAYG schemes and their role in achieving society's equity objectives.

Overall, both the example which considers the economy from the macro perspective and Box 5 make it clear that the ratio of accrued pension liabilities to GDP is not a measure of pension schemes sustainability or, more generally, of public finances sustainability. A high liabilities-toGDP ratio does not necessarily imply an imbalance in the PAYG pension schemes or in the budget. Nor does it imply that an imbalance will occur in the future. The size of the liabilities depends on the decision concerning the benefits and eligibility criteria of PAYG schemes, but it does not provide any information on whether the PAYG system is unbalanced or will be unbalanced in the future.

Any judgement about the sustainability of pension schemes requires estimates about the resources available to pay for the accrued pensions, namely about the evolution of employment and per capita income. Accrued-to-date liabilities do not include such estimates. All one can say is that the larger the ratio of pension rights to GDP, the higher the share of future public resources committed to pension expenditure and the higher the risk that, if GDP growth is not adequate, some adjustment will become necessary (in terms of higher tax rates, of repudiation of pension rights, etc.). Some pension schemes include mechanisms that automatically adjust contributions or benefits to the new developments. 


\section{Pension liabilities and sustainability: is there a link?}

We consider a very simplified economy in the steady state with a constant population structure. We show that the ratios to GDP of both accrued liabilities and pension expenditure are constant over time. As long as the contributory rate is higher than the expenditure ratio this system is sustainable.

We then introduce a demographic shock in the system. The shock will be such that the ratio of liabilities to GDP will be the same as before, but the expenditure ratio will increase over time till above the contributory rate. Therefore, the shock will lead the system to be unbalanced.

This means that, for a given ratio of accrued-to-date liabilities to GDP, a country can be on either a sustainable or an unsustainable path.

The steady state. - Assume that the interest rate is equal to the rate of growth of the amount paid to each pensioner (which is constant so that discounting cancels out). Moreover, assume that pensions accrue at a constant rate during working years (each worker accrues a fraction of the pension $p$ which is inversely proportional to the expected length of the retirement period). GDP is given by the sum of workers' product (which coincide with their wage $w$ ).

The timing in such an economy is as follows: individuals do not work until they reach a certain age $W A$ (working age), then they work till they reach age $R A$ (retirement age) and they benefit from a pension till they reach age $D A$ (death age). This timing is the same for every individual. Population does not grow over time: the birth rate and the death rate are the same so that the number of pensioners and that of workers are both constant over time.

The ratio of accrued-to-date pension liabilities to GDP at time $\mathrm{t}$ is as follows (see Box 4 and take into account the simplifying assumptions mentioned above):

$$
\begin{aligned}
& \frac{\mathrm{L}(t)}{\mathrm{Y}(t)}=\frac{\mathrm{LP}(\mathrm{t})+\mathrm{LW} 1(\mathrm{t})}{\mathrm{Y}(\mathrm{t})}= \\
&=\frac{\sum_{\mathrm{a}=\mathrm{RA}}^{\mathrm{DA}} \mathrm{N}_{\mathrm{a}}^{\mathrm{P}}(\mathrm{DA}-\mathrm{a}) \mathrm{p}+\sum_{\mathrm{b}=\mathrm{WA}}^{\mathrm{RA}} \mathrm{N}_{\mathrm{b}}^{\mathrm{W}} \frac{(\mathrm{b}-\mathrm{WA})}{(\mathrm{RA}-\mathrm{WA})}(\mathrm{DA}-\mathrm{RA}) \mathrm{p}}{\mathrm{N}^{\mathrm{W}} \mathrm{W}}= \\
&=\frac{\mathrm{p}}{\mathrm{W}} \frac{\left(\sum_{\mathrm{a}=\mathrm{RA}}^{\mathrm{DA}} \mathrm{N}_{\mathrm{a}}^{\mathrm{P}}(\mathrm{DA}-\mathrm{a})+\sum_{\mathrm{b}=\mathrm{WA}}^{\mathrm{RA}} \mathrm{N}_{\mathrm{b}}^{\mathrm{W}} \frac{(\mathrm{b}-\mathrm{WA})}{(\mathrm{RA}-\mathrm{WA})}(\mathrm{DA}-\mathrm{RA})\right)}{\mathrm{N}^{\mathrm{W}}}
\end{aligned}
$$

This means that the ratio of accrued-to-date pension liabilities to GDP at time $t$ is given by the ratio of the average per capita benefit to the average per capita wage (which is also the average per capita GDP) times the ratio to the number of workers of the sum of the number of pensioners, weighted for their life expectancy, and the number of workers, weighted for their expected life as pensioners times their share of working life already worked. Given the assumptions on the demographic developments of this economy this ratio is constant over time and depends on the decision concerning the retirement age. The higher RA is, the smaller the pension liabilities are. 
In this context also the pensions expenditure-to-GDP ratio is constant:

$$
\frac{\mathrm{P}(t)}{\mathrm{Y}(t)}=\frac{\mathrm{P}}{\mathrm{Y}}=\frac{\text { pension expenditure }}{\mathrm{GDP}}=\frac{\mathrm{N}^{\mathrm{P}} \mathrm{p}}{\mathrm{N}^{\mathrm{w}} \mathrm{W}}=\frac{\mathrm{N}^{\mathrm{P}}}{\mathrm{N}^{\mathrm{w}}} \frac{\mathrm{p}}{\mathrm{W}}
$$

As long as the ratio of pension expenditure to GDP is less than or equal to the contributory rate $c$ (constant), the system is balanced.

If we compare pension liabilities to pension expenditure, we get:

$$
\frac{\mathrm{L} / \mathrm{Y}}{\mathrm{P} / \mathrm{Y}}=\frac{\frac{\mathrm{p}}{\mathrm{W}} \frac{\left(\sum_{\mathrm{a}=\mathrm{RA}}^{\mathrm{DA}} \mathrm{N}_{\mathrm{a}}^{\mathrm{P}}(\mathrm{DA}-\mathrm{a})+\sum_{\mathrm{b}=\mathrm{WA}}^{\mathrm{RA}} \mathrm{N}_{\mathrm{b}}^{\mathrm{W}} \frac{(\mathrm{b}-\mathrm{WA})}{(\mathrm{RA}-\mathrm{WA})}(\mathrm{DA}-\mathrm{RA})\right)}{\frac{\mathrm{p}}{\mathrm{W}} \frac{\mathrm{N}^{\mathrm{P}}}{\mathrm{N}^{\mathrm{W}}}}}{=\frac{\sum_{\mathrm{a}=\mathrm{RA}}^{\mathrm{DA}} \mathrm{N}_{\mathrm{a}}^{\mathrm{P}}(\mathrm{DA}-\mathrm{a})+\sum_{\mathrm{b}=\mathrm{WA}}^{\mathrm{RA}} \mathrm{N}_{\mathrm{b}}^{\mathrm{W}} \frac{(\mathrm{b}-\mathrm{WA})}{(\mathrm{RA}-\mathrm{WA})}(\mathrm{DA}-\mathrm{RA})}{\mathrm{N}^{\mathrm{P}}}}
$$

So the ratio between liabilities and pension expenditure does not depend either on the average pension or on the average wage. It depends on the ratio to the number of pensioners of the sum of the number of pensioners, weighted for their life expectancy, and the number of workers, weighted for their expected life as pensioners times their share of working life already worked. Basically, for any given $\mathrm{p} / \mathrm{w}$, the ratio depends on the structure of population.

The shock. - Suppose that a "demographic shock" occurs: there are more workers than in the steady state (the baby-boom generation enters the labour force). Assume that this increase in the workforce does not change the accrued-to-date liabilities to GDP. This is possible as long as the new workers imply a proportional increase in accrued liabilities and in overall gross domestic product. If the demographic shock implies an increase in the number of just-entered workers (i.e. an increase in the number of workers of age $\mathrm{WA}+1)$ then, given that in the steady state the number of workers of age $\mathrm{WA}+1$ was $\mathrm{N}_{\mathrm{WA}+1}$, after the shock the number of workers of age WA+1 is $\mathrm{N}_{\mathrm{WA}+1}^{\prime}$ where $\mathrm{N}_{\mathrm{WA}+1}^{\prime}=\alpha \mathrm{N}_{\mathrm{WA}+1}$ and $\alpha>1$. Therefore, after the shock the ratio of accrued liabilities to GDP can be written as follows:

$$
\frac{\mathrm{L}(s)}{\mathrm{Y}(s)}=\frac{\mathrm{L}+(\alpha-1) \mathrm{N}_{\mathrm{WA}+1} \frac{(\mathrm{DA}-\mathrm{RA})}{(\mathrm{RA}-\mathrm{WA})} \mathrm{p}}{\mathrm{Y}+(\alpha-1) \mathrm{N}_{\mathrm{WA}+1} \mathrm{~W}}
$$

where $s$ refers to the period when the shock occurs and $\mathrm{L}$ and $\mathrm{Y}$ are the steady state values of liabilities and GDP, respectively. Therefore, if:

$$
\left\{\begin{array}{l}
(\alpha-1) \mathrm{N}_{\mathrm{WA}+1} \frac{(\mathrm{DA}-\mathrm{RA})}{(\mathrm{RA}-\mathrm{WA})} \mathrm{p}=\mathrm{kL} \\
(\alpha-1) \mathrm{N}_{\mathrm{WA}+1} \mathrm{~W}=\mathrm{kY}
\end{array}\right.
$$


where $k$ is a positive constant, then the increase in the workforce leaves the ratio of accrued liabilities to GDP unchanged. Obviously there is an infinite number of $k$ values for which the system is satisfied. Moreover, the system is satisfied (i.e. the demographic shock can leave the liabilities-to-GDP ratio unchanged) as long as the ratio of the retirement period to the working period, weighted by the ratio of the average pension to the average wage, is equal to that of the steady state liability-to-GDP ratio:

$$
\frac{\mathrm{p}(\mathrm{DA}-\mathrm{RA})}{\mathrm{w}(\mathrm{RA}-\mathrm{WA})}=\frac{\mathrm{L}}{\mathrm{Y}}
$$

In the shock-period the system is still balanced. Indeed, the pension expenditure ratio to GDP is lower than in the steady state (the number of pensioners is the same as before while GDP is higher) while the contributory rate is as before.

Nevertheless over time, as the baby-boom generation retires (i.e. at time $s+[R A-(W A+1)]$, the system will be unbalanced. Indeed at that time, while GDP will return to the steady state value, the pension expenditure will be higher than in the steady state (i.e. $\left[N_{S S}^{P}+(\alpha-1) N_{s}^{W A+1}\right] p$, where $N_{S S}^{P}$ is the pensioners number in the steady state and $(\alpha-1) N_{s}^{W A+1}$ is the number of baby-boom pensioners, i.e. the additional workers as compared to the steady state which were in the labour force at the time the shock $s$ occurred). As $c$ is not likely to be high enough, the system will be unbalanced, i.e. the pension expenditure to GDP ratio will exceed the contributory rate:

$$
\frac{\mathrm{P}(s+[R A-(W A+1)])}{\mathrm{Y}(s+[R A-(W A+1)])}=\frac{\mathrm{P}(s+[R A-(W A+1)])}{\mathrm{Y}(t)}=\frac{\left[\mathrm{N}^{\mathrm{P}}+(\alpha-1) \mathrm{N}_{\mathrm{s}}^{\mathrm{WA}+1}\right] \mathrm{p}}{\mathrm{N}^{\mathrm{w}} \mathrm{W}}>c
$$

Therefore, the ratio of accrued liabilities to GDP does not imply anything in terms of sustainability: the steady state economy and the after-shock economy share the same liability-to-GDP ratio but completely different perspectives in terms of sustainability of the pension system.

A numerical example. - Suppose we have a steady state economy with the following population structure. There are four citizens: one is 10 years old, one is 30 , one is 50 , and one is 70 . Assume that every citizen works from age 20 to age 60 so that the second and the third citizens work; their gross income is $€ 100$ each. The oldest citizen is retired; his pension is $€ 40$. Suppose GDP is equal to the sum of workers' product $(€ 200)$. The contributory rate on workers' income, which corresponds to the ratio of pension expenditure on GDP, is 20 per cent. Assume that incomes and pensions grow at a constant rate and that this rate is equal to the interest rate. ${ }^{35}$ Also assume that pensions accrue at a constant rate during working years (with a present value of $€ 1$ per year), that everyone lives 80 years.

The retired citizen accrued rights amount at $€ 400$ ( $€ 40$ times 10 years of expected life); the two workers' accrued rights amount to $€ 800$ ( $€ 10$ times 20 years of expected life in retirement for the first worker and $€ 30$ times 20 years for the second worker). Altogether, pension liabilities amount to 6 times GDP. As the contributory rate is set to remain stable at 20 per cent and the ratio of pension expenditure to GDP is not going to exceed 20 per cent over time, the system is balanced.

35 In many countries pensions are indexed to price dynamics. Therefore, the assumption that relates them to wage dynamics tends to overestimate pension expenditure. On the other hand, in many countries there are rules that work the opposite way. For instance, pensions are frequently based on the wages earned in the latter part of working life, which are often higher than the average real wage earned during the whole life. 
Now, suppose that there is a demographic shock: the baby boom generation enters the labour market so that the economy is as before, but there are two more people. More specifically, workers aged 50 are now three. Pension liabilities and GDP are, respectively, $€ 2.400$ ( $€ 30$ times 20 years of expected life in retirement times two in addition to the previous $€ 1.200$ ) and $€ 400$ (since there are four workers); the ratio between the two is, as in the steady state, equal to 6 . Pension expenditure is presently 10 per cent of GDP but in 10-years time it will rise to 60 per cent and become unsustainable, given the 20 per cent contributory rate.

Therefore the steady state economy and the post-shock economy share the same accrued-to-date liabilities (which are 6 times GDP) but they are very different in terms of sustainability, i.e. perspective pension developments which depend on their demographic structure.

It can also be argued that a country relying only on PAYG schemes can be in a worse position than a country relying both on PAYG and funded schemes in terms of risk differentiation and the absorption of shocks. However, neither theory nor experience support the view that the recourse to PAYG schemes rather than to funded schemes necessarily implies less sound public finances. ${ }^{36}$

On the other hand, accrued rights measure the cost of closing down a PAYG scheme when fully complying with present rules concerning benefits: ${ }^{37}$ if there is a switch from a PAYG system to a funded system and all new contributions are paid into the new system, accrued rights measure the amount of resources which have to be financed out of general taxation.

4.2.2 Accrued liabilities and public debt. - With reference to accrued-to-date liabilities, it can be argued that "from the worker's point of view, social security "tax" contributions are, in most respects, equivalent to the purchase of a government liability" (Kotlikoff, 1984; p. 567). In fact, an abrupt end to or a radical change in a PAYG scheme would impose large adjustment costs and personal hardships to pensioners and workers who have taken their savings and labour supply decisions on the basis of the existence of the scheme. ${ }^{38}$

Nevertheless, accrued pension rights differ in many ways from conventional public debt (see also Rizzo, 1985, Pedone, 1987 and Bohn, 1992).

36 The PAYG versus funding argument is very complex and is beyond the scope of this paper. See, for instance, the papers in OECD (1992) and Sartor (1993).

37 See World Bank (1994).

38 According to Bohn (1992, p. 4), "One should distinguish between a social-security system in its start-up phase, where the first generation of participants receive substantial "unearned" benefits, and a more mature system. Since promises to make gift are generally unenforceable, the benefits promised in the start-up phase cannot be considered government liabilities. On the other hand, it is difficult to imagine that a government could cancel the socialsecurity benefits of retirees who have made social security contributions throughout their life." This distinction, although appealing, is not easily applied. 
First of all, while the timing of the repayment of public bonds as well as the amount to be paid to the holders are fixed in advance, those of pension liabilities are uncertain. ${ }^{39}$ Indeed, they depend on decisions made by the holders of the entitlements (concerning, for instance, the age of retirement, where some flexibility is allowed) and on various types of events (those concerning the length of life, wage and price dynamics, etc.). ${ }^{40}$

Second, pension rights are not embodied in formal contracts. The debtor can modify both the timing and the amount of the payment. While failure to repay financial liabilities may give rise to legal claims and political reactions, the repudiation of PAYG pension liabilities may raise only the latter. ${ }^{41}$ Pension liabilities can be reduced by changing benefit rules: major pension reforms have reduced the future entitlements of current workers and pensioners. Indexation mechanisms, retirement ages, eligibility rules and other aspects of the pension system have been frequently modified in recent years in developed countries. ${ }^{42}$ Consequently it would be erroneous to assume that pension programs represent a firm legal or moral commitment. ${ }^{43}$

Moreover, while public bonds are usually bought freely on the market by individuals or companies, the acquisition of pension rights is usually compulsory. This means that a large pension-debt does not determine any direct pressure on the financial markets. ${ }^{44}$ It also implies that the debt is automatically renewed.

Finally, pension rights are not tradable. This implies that changes in the relative yield and the relative risk of pension rights comparatively to other assets have no effect on financial markets. It also implies less protection for pension-right holders than for bond holders. Bohn (1992, p. 45) notes that: "For government debt, any attempt to default - outright or through inflation - would imply undesirable market disruptions. Such "protection" against default does not exist for socialsecurity claims. In addition, non tradability implies that social-security claims could be altered selectively, taking individual characteristics (e.g., income, demographics) into account."

39 For a general analysis of government contingent liabilities see Towe (1991).

40 The elasticity of pensions to price and wage changes is frequently different from 1.

41 On the political-economy of support to pension expenditure see Buchanan (1983), Rizzo (1985) and Tabellini (1990).

42 The Italian pension reform of 1992 provides a clear case: 30 per cent of the pension-debt was wiped out at a time when public finances were considered to be in a very critical situation.

43 One should nevertheless consider that the implementation of large cuts in pension rights may obviously raise political reactions and that these reactions are likely to increase with the gradual shift of political power towards the older generations. As Börsh-Supan (1991, pp; 129-130) notes: "In West Germany after 2020 the majority of the voters will be pensioners and workers who will become retired within the next 10 years. We then risk facing a typical free-rider situation as the older generation can outvote the younger generation in determining their retirement income as well as the rate of social security taxes the younger generation has to pay."

44 A large future pension expenditure may obviously influence the attitude towards public bonds, but this is an indirect effect. 


\subsubsection{Accrued-to-date pension liabilities and fiscal policy assessment with reference to EMU debt.}

- The previous Sub-section has pointed to the differences between accrued pension liabilities and public debt. In the EMU framework the inclusion of pension liabilities in the public debt definition would raise additional problems.

First, conventional public debt can be measured rather precisely and unambiguously at any point in time. Pension liabilities are uncertain and depend on the specific assumptions adopted upon a variety of factors, such as life expectancy, price and wage trends. Present value calculations are extremely sensitive to changes in assumptions. ${ }^{45}$ This is particularly problematic in a context where figures are to be provided for 25 countries.

Second, as pension rights are acquired compulsorily and are not tradable, they produce no direct effect on financial markets. The inclusion of pension liabilities in the debt and deficit measures would obscure the pressure of the public sector on financial markets. ${ }^{46}$

Third, the inclusion of pension liabilities in the public debt definition would either require an analogous change in the deficit definition or enlarge the degree of incoherence between the two indicators European fiscal rules refer to. Let us consider the first case. Currently contributions are recorded as government revenue and pensions as payments to retirees. The change would imply that contributions are classified as loans to the public sector, which would not be taken into account in computing the deficit indicator (Oksanen, 2004). Pensions would be considered as loan repayment. In this accounting system, an increase in contribution rates would, ceteris paribus, have no effect either on current or future deficits. ${ }^{47}$ Any increase in the benefits promised for the future would increase current deficit and leave future ones unchanged. These changes would blur any indications concerning the impact of the fiscal policies of each country on the area fiscal stance. Although pension liabilities surely affect consumption and saving decisions, ${ }^{48}$ the magnitude of the impact is not necessarily equal to that of public financial liabilities. Pension rights holders may have limited foresight, may not trust present or future government's capacity to deliver the full pensions they are entitled to under present rules, may be cash-constrained, may live in a world with imperfect capital

45 As Boskin et al. (1987, p. 45) point out, referring to the USA: "Moving all of the economic and demographic projections from intermediate to either optimistic or pessimistic (assumptions) results in a change which is larger than the privately held national debt." The effects on deficit estimates would even be relatively larger.

46 The case of Italy may again be relevant. Despite the fact that the 1992 reform wiped out pension liabilities equal to Italian conventional debt, the role of the public sector in the financial markets have not changed significantly.

47 It has also been suggested that part of the repayment be considered an implicit interest payment. This solution is supported by Kotlikoff (1984). Towe (1991, p. 117) notes that "proponents of this system do not address the issue of decomposing benefit payments into "principal" and "interest". Presumably, actuarial criteria could be applied." In this case, the impact of changes in current contribution rates would depend on the link between contributions and benefits.

48 As to savings, see for instance Rossi and Visco (1994) who suggest that the growth of PAYG schemes' liabilities contributed substantially to the decline in Italian saving ratio between the 1960 s and the 1980 s. 
markets. The inclusion of pension rights in debt and deficit statistics on a one-to-one basis might, therefore, lead to an erroneous estimate of the impact of fiscal policy. ${ }^{49}$

Fourth, the addition of pension liabilities to the conventional public debt would produce misleading indications of the effects of changes in interest rates on public expenditure perspectives and budgetary sustainability. Since accrued pension liabilities are negatively related to the level of the interest rate, any increase in this level would automatically reduce total debt. This development can look like an improvement however it might correspond to an actual worsening of budgetary conditions due to the increase in interest expenditure.

Fifth, the inclusion of pension liabilities in debt and deficit statistics would obviously influence international comparisons of public finance data. The amount of the total public debt would depend on the structure of the pension system. More specifically, the countries relying on PAYG schemes would record a higher debt than those relying on funding. But one can wonder why pension expenditure should be treated differently as compared to other types of expenditure. To some extent, all spending programmes create implicit contracts containing future liabilities. On this point Brittan (1993) takes a radical view: "The fallacy of such estimates (of pension liabilities) is to treat pension commitments differently from other forms of public spending. The PAYG schemes, from which the scare stories stem, are based on each generation of workers paying through taxes and contributions sufficient to cover the cost of pensions for those already retired. Thus, pensions are, like any other form of rising public expenditure, to be met from higher tax revenue or social security contributions, or reduced spending elsewhere." 50

Finally, the inclusion of pension liabilities in the public debt definition, by making citizens' entitlements more explicit, might produce negative effects on the pension reforms needed to ensure fiscal sustainability in several European countries. ${ }^{51}$

4.3 New net liabilities and the sustainability of PAYG schemes. - Present pensioners and workers' liabilities and open-system liabilities include net pension rights that are yet to accrue. Strictly speaking, these pension rights should not even be called liabilities but potential liabilities. They cannot therefore be in any way assimilated to conventional public debt, which is a backward looking indicator.

49 This point is extensively examined in Mackenzie (1989).

50 Penner (1982, p. 234) notes that: "One might argue that the degree of political commitment to future pensions is somewhat stronger than to other entitlements in that pension benefits seem much harder to cut than other entitlements. But neither are cut very often, and this is admittedly a weak argument." See also Kuné (1996).

51 Boskin (1982) notes that: "I would not wish to have the current rules and regulations of the social insurance program cemented into a unified capital account of the government as if we had issued explicit long-term contractual debt obligations, that is, I do not want to enshrine pay-as-you-go financing of these programs and government activities at current projected levels." 
As already mentioned, new expected rights may play a role in the assessment of the perspectives of pension schemes. Future rights are positive when the discounted flow of benefits is higher than the discounted flow of contributions; they are negative when the former flow is smaller than the latter. We now turn to the possible economic and sustainability implications of positive and negative net future rights.

In a "pure" PAYG system in any period the total amount of pensions paid out is given by the total amount of contributions:

$$
\mathrm{p} \mathrm{N}^{\mathrm{P}}=\mathrm{cw} \mathrm{N} \mathrm{N}^{\mathrm{w}}
$$

where $p$ is the average pension, $N^{P}$ represents the number of pensioners, $c$ is the contribution rate levied on wages, $w$ is the average wage and $N^{w}$ represents the number of workers.

If $c$ is constant over time, $w, N^{P}$ and $N^{w}$ dynamics are exogenous and $p$ is adjusted in each period of time in order to balance expenditures with revenues (i.e. there is a "pure" PAYG system), it can be shown that the rate of return on contributions $(r c)$ is approximately equal to the sum of the rates of growth of per capita wages $(\dot{w})$ and of the number of workers $\left(\dot{n}_{\mathrm{w}}\right){ }^{52}$

$$
r c=\dot{w}+\dot{n}_{\mathrm{w}}
$$

To grasp the intuition underlying this result, think of a two-period economy. In the first period individuals work and pay contributions. In the second period individuals get a pension. Overall pension expenditure in each period is equal to the contributions paid in the same period by the generation which is currently working. Pensioners get a pension which depends on the number of working individuals and on the wage of those individuals. Therefore, the return on the contributions paid in the previous period by today's pensioners depends on the growth rate of the number of workers and on the growth rate of wages.

A "pure" PAYG pension policy is sustainable, in the sense that it does not require any change in rules, as long as $r c=w+n_{\mathrm{w}}$.

In practice, most PAYG systems are not "pure" systems, i.e. $p$ is not adjusted in each period of time in order to balance expenditures with revenues. In other words, $r c$ is not necessarily equal to $w+n_{\mathrm{w}}$.

Net pension rights are positive if the implicit return on contribution is greater than the return rate assumed as a benchmark (i.e. if $r c>r$ ) but the sign of net pension rights does not convey any information on whether or not there is an imbalance in the PAYG scheme. The amount of pension rights does not provide any information on whether the rate of return on contributions is either larger or smaller then the sum of the rate of growth of per capita wages and of the rate of growth of 
the number of workers (i.e. whether $r c>\dot{w}+\dot{n}_{\mathrm{w}}$ or $r c<\dot{w}+\dot{n}_{\mathrm{w}}$ ) which is the relevant aspect in assessing the need to modify pension policy.

The sign and the dimension of pension rights crucially depend on the choice of $r$, which is rather arbitrary. If $r$ is very high, even a scheme where $r c$ is much higher than $w+n_{\mathrm{w}}$ would show negative net rights. Conversely, if $r$ is very low, even a scheme where $r c$ is much lower than $w+n_{\mathrm{w}}$ would show positive net rights.

In conclusion, positive net rights do not imply that the pension system is presently unbalanced in cash terms or that it will become unbalanced within a certain time. Neither do they imply that some adjustment will have to take place in the future. On the other hand, there may exist circumstances in which even with null or negative new expected rights the pension system can exert large cash pressure on the budget.

It would be more relevant to provide estimates of $r c$ and to compare them with present and future values of $w+n_{\mathrm{w}}$ (this is precisely the indication provided by the equilibrium contributory rate). Unless one assumes that a certain rate of return on contributions represents a normative benchmark for the assessment of PAYG schemes, any comparison between $r c$ and an arbitrary $r$ does not lead very far.

Had estimates of new net rights been carried out in the 1960s and the 1970s, they would have probably shown large positive values because $r c$ was in many countries higher than it is now. The large positive values would have implicitly signalled that citizens were granted very high returns on contributions and that these returns were unlikely to be continuously matched by a high level of $\dot{w}+\dot{n}_{\mathrm{w}}$. The availability and the diffusion of estimates might have limited the tendency to improve pension benefits and might have accelerated the reform of pension schemes. Recent estimates, that take the reforms of the 1980s and the 1990s into account, are apparently less worrying. Van den Noord and Herd (1993) record negative or nearly null new net rights in four out of the seven countries that they consider. In spite of that, due to the decline in $w+n_{\mathrm{w}}$, the situation of pension systems is very worrying: a declining number of new workers is being called to service a large accrued debt.

In a way, estimates of future net rights were not available when they were mostly needed. Now that they are available, it is apparent that in many countries the problem does not lie in avoiding that future net rights have positive values but in cutting accrued rights and in getting new generations of workers to accept negative net rights.

4.4 Estimates of pension liabilities. - Estimates of pension liabilities are subject to measurement errors and to misinterpretation, as the projections for pension expenditure. They are based on specific assumptions concerning a variety of factors, such as future labour force participation rates, retirement behaviour, unemployment, prices and earnings. As for demographic calculations, forecasts rely on techniques for projecting future pension payments from available data on current 
and past trends. Estimates can be based on administrative data concerning the work history of individuals or on panel data tracking the economic activity of successive cohorts of individuals.

The first international comparisons of pension liabilities were provided in 1989 by Hagemann and Nicoletti and in 1993 by Van den Noord and Herd and by Kuné et al. The first and the second works were prepared within the OECD, the third within ABP. ${ }^{53}$ Hagemann and Nicoletti (1989) refer to pension scheme accounts in 1985; the other authors refer to 1990 accounts. The countries considered do not coincide. Only Germany is considered in all three papers. Before examining the data, however, it is necessary to consider some methodological issues.

The studies are based on a highly simplified methodology. In Van den Noord and Herd (1993), for each country a "full pension" (which is actually an average pension) is computed dividing total public expenditure on pensions by the number of beneficiaries. The present value of current benefits is estimated on the basis of the full pension, of mortality rates and of a discount rate. Pensions are supposed to be held constant in real terms. The paper shows that estimated pension liabilities on average are about twice as large as conventional debt; future pension rights are projected to generate liabilities amounting to 3.5 times the GDP, almost twice as much as the level of liabilities associated with existing entitlements. Furthermore, countries with high debt-to-GDP ratio also tend to have high pension liabilities to GDP ratio.

In estimating the pension rights of current workers, Van den Noord and Herd (1993) assume that in each country the standard retirement age is 60 , and the number of years of contributions required for a full pension ${ }^{54}$ is 40 . They also assume that pension entitlements accrue at a constant rate of 1/8 of the full pension every five-contribution years. Present workers are grouped in eight five-year brackets. The members of each bracket are assumed to be entitled to the same pension rights. During working life, pension entitlements are projected to grow at the same rate as projected real earnings and real output per worker. This means that the ratio of the average new pension to real earnings per worker is held constant. An exception is made for Canada and the United Kingdom "where pension rates undergo a structural upgrading". 55

Kuné et al. (1993) follow broadly the same lines. Standard retirement age is nevertheless assumed to be 65, and no structural upgrading is considered. In Van den Noord and Herd (1993) the different PAYG schemes existing in each country are considered as a single "average" system; in Kuné et al. (1993) the present value of pension rights is estimated separately for public sector and private sector workers.

53 ABP (Algemeen Burgerlijk Pensioenfonds) is the pension fund of the Dutch public employees. The paper was prepared for CEPS Working Party on "Financing Retirement Provision in Europe".

54 That is for a pension equal to the 1990 average pension.

55 Structural upgrading may depend on younger generations of citizens retiring with longer contributory periods or with more favourable rules concerning the determination of the pension paid. 
In Van den Noord and Herd (1993) the discount rate is 4 per cent in real terms in the period 19902010; after that, it gradually declines reaching 3 per cent in 2050. An alternative projection with a discount rate 1.5 per cent higher than in the baseline is also presented. In Hagemann and Nicoletti (1989) the discount rate is set at 2 per cent for Germany, Sweden and the US and at 3.5 per cent for Japan. In Kuné et al. (1993) the discount rate is 4 per cent for the whole projection period.

In all the papers some assumptions are clearly unsatisfactory.

- In many countries younger pensioners, who obviously live longer, receive, on average, higher pensions than older ones. The assumption that pension level is uniform tends to underestimate the present value of current pensioners' rights. Besides, the use of the current average pension as the term of reference for the level of future pensions may lead to erroneous estimates. Estimates may turn out too low if pension levels undergo a structural upgrading, and too high if rules concerning the level of new pensions have been tightened.

- In some countries (like Germany and Italy up to 1992) pensions are also indexed to real wage increases. Holding pensions constant in real terms determines an underestimate of liabilities. ${ }^{56}$

- Hagemann and Nicoletti (1989) and Van den Noord and Herd (1993) do not provide separate estimates for public and private sector workers. This may lead to some underestimation of liabilities since in many countries in the last decades public employment has grown faster than total employment, and public employees usually have better retirement rules.

- Kuné et al. do not take into account that some pension systems may not yet have reached maturity (i.e., that the ratio of average new pensions to average earnings may increase over time). Hagemann and Nicoletti (1989) consider structural upgrading for Japan and Sweden. Van den Noord and Herd (1993) consider it for Canada and the UK. ${ }^{57}$

Table 2 presents the estimates of accrued pension liabilities according to Van den Noord and Herd (1993) and Kuné et al (1993). The data concerning the four major EU Member States show that estimates vary considerably: UK's liability ranges between 42 and 139 per cent of GDP, France's between 69 and 216. Van den Noord and Herd (1993) provide the highest estimates and Kuné et al. (1993) the lowest. The ranking of the four countries is very different: Germany comes first according to Kuné et al. (1993) and third according to Van den Noord and Herd (1993).

56 Van den Noord and Herd (1994) provide an estimate of the pension liabilities of the seven major western countries under the assumption that all pension benefits after retirement are indexed to earnings. Accrued pension liabilities are 10 to 20 per cent higher than in the case of price indexation.

57 As regards Italy, for instance, only one third of the increase in the ratio of public pension expenditure to GDP between 1960 and 1990 may be attributed to demographic changes (Franco, 1993). The increase in the pension to GDP ratio that was forecast before the 1992 pension reform was also largely attributed to the maturation of pension schemes. 
Public pension liabilities: present value of accrued rights

(as a percentage of 1990 GDP)

\begin{tabular}{|c|c|c|c|c|c|c|c|c|}
\hline \multirow{3}{*}{ Country } & \multicolumn{5}{|c|}{ Van den Noord and Herd (1993)* } & \multirow{2}{*}{\multicolumn{3}{|c|}{$\begin{array}{c}\text { Kuné et al. (1993) } \\
\text { Gross liabilities }\end{array}$}} \\
\hline & \multicolumn{3}{|c|}{ Gross Liabilities } & \multirow{2}{*}{$\begin{array}{l}\text { Existing } \\
\text { assets }\end{array}$} & \multirow{2}{*}{$\begin{array}{c}\text { Net } \\
\text { liabilities }\end{array}$} & & & \\
\hline & Retired & Workforce & Total & & & $\begin{array}{c}\text { Civil } \\
\text { Servants }\end{array}$ & $\begin{array}{l}\text { Non Civil } \\
\text { Servants }\end{array}$ & Total \\
\hline Belgium & & & & & & 30 & 38 & 68 \\
\hline Denmark & & & & & & 0 & 69 & 69 \\
\hline Germany & 54 & 103 & 157 & - & 157 & 50 & 72 & 122 \\
\hline Greece & & & & & & 16 & 102 & 118 \\
\hline Spain & & & & & & 13 & 96 & 109 \\
\hline France & 77 & 139 & 216 & - & 216 & 31 & 38 & 69 \\
\hline Ireland & & & & & & 8 & 46 & 54 \\
\hline Italy** & 94 & 148 & 242 & - & 242 & 29 & 78 & 107 \\
\hline & $(94)$ & (165) & (259) & & (259) & & & \\
\hline Luxembourg & & & & & & 25 & 113 & 138 \\
\hline Netherlands & & & & & & 0 & 137 & 137 \\
\hline Portugal & & & & & & 16 & 80 & 96 \\
\hline UK & 58 & 81 & 139 & - & 139 & 0 & 42 & 42 \\
\hline USA & 42 & 70 & 113 & 23 & 89 & & & \\
\hline Japan & 51 & 112 & 163 & 18 & 144 & & & \\
\hline Canada & 42 & 71 & 113 & 8 & 105 & & & \\
\hline
\end{tabular}

Source: Franco (1995).

* Data for Canada and the UK have been updated as in Van den Noord-Herd (1994).

** Figures in brackets are estimates of liabilities before the 1992 pension reform.

Furthermore, in the by estimates Van den Noord and Herd (1993), pensioners' rights represent 30 to 40 per cent of total rights. In the estimates by Kuné et al. (1993), civil servants' rights represent 40 per cent of total pension rights in Belgium, Germany and France. It is a much higher percentage than their incidence in the labour force. This supports the view that pension liabilities ought to be estimated separately for all the major schemes with different rules existing in any country.

Table 3 shows some estimates of current workers and pensioners' net liabilities and open-system net liabilities. It should be noted that Kuné et al. do not take into account the future flow of 
Table 3

Public pension liabilities: present value of future pension entitlements

(as a percentage of $1990 \mathrm{GDP}$ )

\begin{tabular}{|c|c|c|c|c|c|c|c|c|c|}
\hline \multirow{2}{*}{ Country } & 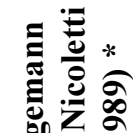 & \multicolumn{5}{|c|}{ Van den Noord and Herd (1993) ** } & \multicolumn{3}{|c|}{ Kuné et al. (1993) } \\
\hline & 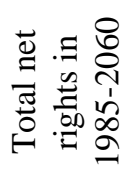 & 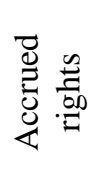 & 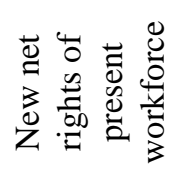 & 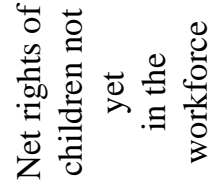 & 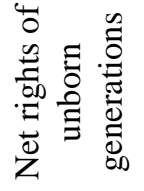 & $\stackrel{\vec{\pi}}{0}$ & 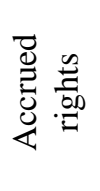 & 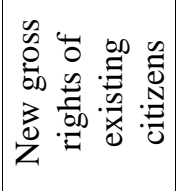 & స్ّ \\
\hline Belgium & & & & & & & 68 & 44 & 112 \\
\hline Denmark & & & & & & & 69 & 28 & 97 \\
\hline Germany & 355 & 157 & -8 & -2 & 13 & 160 & 122 & 57 & 179 \\
\hline Greece & & & & & & & 118 & 78 & 196 \\
\hline Spain & & & & & & & 109 & 74 & 183 \\
\hline France & & 216 & -16 & -7 & 23 & 216 & 69 & 37 & 106 \\
\hline Ireland & & & & & & & 54 & 49 & 103 \\
\hline Italy $* * *$ & & 242 & -60 & -36 & -45 & 101 & 107 & 77 & 184 \\
\hline & & (259) & $(-22)$ & $(-11)$ & (8) & (223) & & & \\
\hline Luxembourg & & & & & & & 138 & 99 & 237 \\
\hline Netherlands & & & & & & & 137 & 73 & 210 \\
\hline Portugal & & & & & & & 96 & 71 & 167 \\
\hline UK & & 139 & -23 & -12 & -3 & 100 & 42 & 28 & 70 \\
\hline USA & 158 & 112 & -21 & -14 & -11 & 66 & & & \\
\hline Japan & 217 & 163 & 10 & 8 & 38 & 218 & & & \\
\hline Canada & & 105 & 16 & 14 & 57 & 191 & & & \\
\hline
\end{tabular}

* Percent of 1985 GDP. Swedish liabilities are estimated as 183 or 228 percent of GDP according to pension indexation to prices or to wages.

** Data for Canada and the UK have been updated as in Van den Noord-Herd (1994).

*** Figures in brackets are estimates of liabilities before the 1992 pension reform. 
contributions to PAYG schemes. This tends to overestimate pension liabilities. Van den Noord and Herd (1993) assume that in five of the seven countries considered, contributions to PAYG schemes are going to be equal, with respect to GDP, to the incidence of their expenditure on GDP in $1990{ }^{58}$ This means that no part of 1990 public budget deficits is attributed to public pension schemes. There follows an underestimation of future liabilities of pension schemes. For the two remaining countries, contributions are computed at present rates. The latter methodology is also applied by Hagemann and Nicoletti (1989). ${ }^{59}$

Van den Noord and Herd (1993) provide estimates regarding present workers, children not yet in the workforce and unborn citizens. According to the paper, "A positive number in such an account implies a net debt of the government to a specific generation, and hence a net transfer of wealth to that generation. Similarly, a negative number represents a net debt of a particular generation to the government and hence a net transfer of wealth to that generation". 60

According to these estimates, in Canada and Japan rights for new generations are accruing faster than contributions. Some adjustment to contribution rates or benefit rules would therefore be necessary in order to avoid new transfers of resources to pensioners. In France and Germany "accruals of contributions would broadly match new accruals of pension rights (while leaving the existing accruals unfinanced)". 61 In Italy, the United Kingdom and the United States future generations have already "been called to transfer wealth to current generations". This does not imply that in the latter countries there is scope for improving benefits or for cutting contribution rates.

Hagemann and Nicoletti (1989) provides an estimate of the unfunded pension liabilities of all individuals aged 17 to 90 years in 1985. Its results should be comparable with the sum of Van den Noord and Herd (1993) accrued rights and new net rights of the present workforce. Again, the estimates differ very much: 355 per cent of GDP in Hagemann and Nicoletti (1989) as against 149 per cent in Van den Noord and Herd (1993) for Germany, 158 per cent as against 91 per cent for the USA, 217 per cent as against 173 per cent for Japan (Table 3). A part of the difference surely depends on the assumptions about the discount rate. In the case of Germany it may also depend on the different methodologies used in estimating future contributions.

The different solutions adopted by Van den Noord and Herd (1993) and Kuné et al. (1993) for evaluating future contributions also explain the different results in Table 2 and Table 3.

The countries are Canada, France, Germany, Italy and the United Kingdom.

59 As to the USA, legislated future increases contribution rates are taken into account.

$60 \operatorname{OECD}(1993$, p. 54).

61 But this would not matter as long as the PAYG systems were not terminated. 
Table 4 reports the results of some estimates of pension liabilities carried out at national level in more analytical terms. ${ }^{62}$ UK and Italian estimates are rather larger than those presented in Tables 2 and $3 .^{63}$ In the case of Italy there is a huge difference in the estimates of liabilities existing before the 1992 pension reform and in the estimates of the effects of the reform. Van den Noord and Herd (1993) results concerning Italy, which also contrast with those of other studies concerning the perspectives of the Italian pension system, ${ }^{64}$ depend largely on the overestimation of future contribution and on the underestimation of benefits arising from the assumption considered above.

National studies show that in some countries the ratio of pension liabilities to GDP has grown considerably during the last decades; accordingly, in these countries, economic deficits have been much larger than conventional cash flow deficits. The inclusion of the change in liabilities in deficit statistics would have increased the Italian deficit by 11 points of GDP every year between 1971 and 1981 and by 5 points every year between 1981 and 1991 .

Chand and Jaeger (1996) estimate discounted net pension liabilities, defined as current accrued rights of pensioners and workers plus the prospective liabilities that will be accumulated in the future. Furthermore, the paper estimates the primary balance required to finance these projected pension liabilities (Table 5).

According to the paper, net pension liabilities range from 5 per cent of GDP for the United Kingdom to about 110 per cent of GDP for France, Germany and Japan. The authors add these liabilities to the net public debt and argue that if “one judges the sustainability of a nation's fiscal stance in terms of the conventional criterion of stabilising net public debt at its current levels, it would appear that the present fiscal stance of Italy and Germany are sustainable: their projected primary balances in 1995 exceed the amounts needed to stabilise the ratio of net public debt (excluding pension liabilities) to GDP". Given that the assumed interest rates are higher than projected real growth rates, primary surplus has to be high enough to offset the growth in debt ratio due to interest rates. "However, if account is taken of the projected buildup in net pension debt, and the sustainability criterion is modified to include as well the prevention of any buildup of pension debts, primary surpluses would have to be even higher".

Disney (2001) criticises the methodology adopted by Chand and Jaeger because they put together calculations on an accrual basis (column 1) with projections (column 2) and cash flows (column 3). The projected net liabilities incorporate future flows of contributions that will generate further

62 Some papers providing estimates for Argentina, Chile, China, Colombia and Turkey are indicated in World Bank (1994).

63 The gross liabilities of Italian pension schemes have been estimated also in Pench (1993), which discounts the flow of expected pension expenditure up to the year 2025. The paper aims at evaluating the permanent (seignorageadjusted) primary surplus excluding pensions required to ensure fiscal policy sustainability; for that reason it does not deduct future contributions from future expenditure.

64 INPS (1993), Ragioneria Generale dello Stato (1994), Castellino (1994). 
liabilities. Moreover, instead of solving for the equilibrium PAYG contribution rate required to finance future expenditures, the rate is arbitrarily fixed at its current level, which may not be sustainable. This generates an arbitrary net pension liability, which is then added to an existing one (net public debt). Finally, the "sustainable" primary balance is added to a cash flow measure (the current budget balance) to generate a fiscal adjustment. On the contrary, Disney suggests a different method consisting in starting with the net public debt and add to it a net pension liability based on accrued pension liabilities to date and then find the primary balance required to service such a resulting debt.

Table 4

Public pension liabilities: national studies

\begin{tabular}{|c|c|c|c|c|c|}
\hline Country & Author & Year & Definition & $\begin{array}{c}\text { Liabilities/ } \\
\text { GDP }\end{array}$ & In Year \\
\hline \multirow[t]{7}{*}{ Italy } & Castellino & 1985 & $\mathrm{~L}^{1}$ & 317 & 1983 \\
\hline & Beltrametti & 1993 & $\mathrm{~L}^{2}$ & 153 & 1961 \\
\hline & & & & 303 & 1971 \\
\hline & & & & 317 & 1981 \\
\hline & & & & 368 & 1991 \\
\hline & Beltrametti & 1994 & $\mathrm{~L}^{2}$ & 389 (1) & 1992 \\
\hline & & & $\mathrm{L}^{2}$ & $278(2)$ & 1992 \\
\hline \multirow[t]{4}{*}{ USA } & Feldstein & 1974 & $\mathrm{~L}^{2}$ & 71 & 1960 \\
\hline & & & & 111 & 1970 \\
\hline & Bohn & 1992 & $\mathrm{~L}^{1}$ & $50-90(3)$ & 1989 \\
\hline & & & & $+27(4)$ & \\
\hline UK & Hills & 1984 & $\mathrm{~L}^{1}$ & $198 / 214$ & 1982 \\
\hline
\end{tabular}

Before 1992 pension reform. - (2) After 1992 pension reform. - (3) Social Security. - (4) Civil Service and Military.

$\mathrm{L}^{1} \quad=$ Accrued to date liabilities.

L2 = Current workers' and pensioners' liabilities. 
Table 5

\section{Net pension liabilities and sustainability of fiscal stance}

\begin{tabular}{|c|c|c|c|c|c|}
\hline Country & $\begin{array}{l}\text { Net public } \\
\text { debt, } \\
\text { end } 1994^{\mathrm{A}} \\
\text { (1) }\end{array}$ & $\begin{array}{l}\text { Net pension } \\
\text { liability } \\
1995-2050^{\mathrm{B}} \\
\\
\text { (2) }\end{array}$ & $\begin{array}{c}\text { Sustainable primary } \\
\text { balance to stabilise } \\
\text { debt } \\
(1+2) \\
\text { as percent of GDP } \\
\text { (3) } \\
\end{array}$ & $\begin{array}{c}\text { Primary balance } \\
1995 \\
\text { as percent } \\
\text { of GDP } \\
\\
\text { (4) } \\
\end{array}$ & $\begin{array}{l}\text { Adjustment to } \\
\text { primary balance } \\
\text { for fiscal } \\
\text { sustainability } \\
\text { (3-4) } \\
\text { (5) }\end{array}$ \\
\hline United States & 63.3 & 25.7 & 1.9 & 0.4 & 1.5 \\
\hline Japan & 33.2 & 106.8 & 3.6 & -0.2 & 3.8 \\
\hline Germany & 52.5 & 110.7 & 4.5 & 2.4 & 2.1 \\
\hline France & 42.4 & 113.6 & 4.0 & -0.3 & 4.3 \\
\hline Italy & 112.9 & 75.5 & 4.6 & 3.3 & 1.3 \\
\hline UK & 37.7 & 4.6 & 0.8 & 0.4 & 0.4 \\
\hline Canada & 71.6 & 67.8 & 4.7 & 0.2 & 4.5 \\
\hline Sweden & 54.5 & 20.4 & 1.0 & -5.1 & 6.1 \\
\hline
\end{tabular}

Source: Chand and Jaeger (1996).

(A) Adjusted for net assets of public pension funds at the end of 1994. Estimate of net public det for Germany includes unification debt as of the end of 1994.

(B) Net present value of difference between projected primary expenditure and revenue of public pension fund during 1995-2050, adjusted for net asset position of public pension systems at the end of 1994 .

Frederiksen (2001) aims at estimating the immediate and permanent adjustment of the primary surplus required to forestall the need for further future changes of fiscal policy. He follows two approaches. The first one consists in a comparison between the actual pattern of fiscal consolidation (basically, the actual structural deficit) and the required pattern of consolidation. The latter reflect the need to offset the projected future decrease in the primary surplus due to greater age related spending, as estimated by the AWG.

In the second approach, Frederiksen compares the actual structural primary surplus with the "required" primary surplus. The latter is measured estimating the interest burden both on the explicit net debt and on the implicit debt reflecting the future budgetary consequences of current legislation. In 2000, in the nineteen countries considered the ratio of government net explicit liabilities to GDP amounted on average to 46 per cent. The implicit liabilities amounted to 194 per cent of GDP. This 
implies that, according to OECD estimates, the "official" net debt amounted to only one-fifth of the effective debt burden.

In principle, the two approaches should give the same results to the extent that the assumed constant interest rate is a good proxy of the return on current government financial assets and liabilities. ${ }^{65}$ The average improvement of the primary balance required for the nineteen countries is actually the same (2.3 per cent of GDP) but there are some significant differences at the country level.

Frederiksen (2001) reports the changes in the pension expenditure-to-GDP ratio and the total amount of implicit liabilities (which are based on the open system methodology). The relative position of most countries remains the same either when countries are ranked on the basis of the changes in ratio of pension expenditure to GDP or on the basis of implicit liabilities. The countries with highest expenditure growth are those with the greatest liabilities. Exceptions are represented by Australia, Denmark, Germany, the Netherlands, Portugal and Sweden (Table 6).

On the contrary, the ranking of countries in terms of the current spending levels (see OECD, 2001) does not correspond to their ranking in terms of implicit liabilities. One can expect that countries with the highest pension expenditure-to-GDP ratios have the greatest accrued liabilities, but they do not necessarily have the greatest open system liabilities.

This survey clearly indicates that there is considerable uncertainty concerning the size of pension liabilities and that different definitions of liabilities point to very different assessments of country positions.

\section{Expenditure projections versus liabilities}

Expenditure projections and liabilities provide different indications concerning the future of pension schemes. Expenditure projections are a flow concept. They do not require any discounting but they must be compared with a relevant denominator. Liabilities are a stock concept. They are computed by discounting future flows.

Expenditure projections and liabilities refer to different future flows. In terms of the definition developed in Section 4, expenditure projections implies taking into account (a) all the accrued liabilities of pensioners and workers, (b) the gross liabilities of current workers (i.e. the gross value of the workers' component of the second liabilities definition) and (c) the gross liabilities of perspective workers (i.e. the gross value of the perspective workers' component of the third liabilities definition).

65 The main assumptions are a nominal GDP growth rate of 4 per cent and a nominal rate of interest equal to 6 per cent. Consequently, the growth-adjusted rate of return is 2 per cent. 
Table 6

Pension expenditures and implicit liabilities in Frederiksen (2001)

(as a percentage of GDP in 2001)

\begin{tabular}{|c|c|c|c|c|}
\hline Country & $\begin{array}{l}\text { Ranking for changes in } \\
\text { pensions to GDP ratio }\end{array}$ & $\begin{array}{l}\text { Changes in } \\
\text { pension } \\
\text { expenditure }\end{array}$ & $\begin{array}{c}\text { Ranking for } \\
\text { implicit liabilities }\end{array}$ & Implicit liabilities. \\
\hline Australia & 15 & 1.8 & 10 & 227 \\
\hline Austria & 12 & 2.5 & 13 & 207 \\
\hline Belgium & 11 & 3.5 & 12 & 212 \\
\hline Canada & 3 & 5.8 & 2 & 379 \\
\hline Denmark & 13 & 2.3 & 16 & 143 \\
\hline Finland & 6 & 4.7 & 4 & 371 \\
\hline France & 10 & 3.9 & 8 & 237 \\
\hline Germany & 5 & 5.0 & 14 & 180 \\
\hline Greece & 9 & 4.0 & 9 & 229 \\
\hline Ireland & 7 & 4.4 & 6 & 270 \\
\hline Italy & 18 & 0.0 & 17 & 79 \\
\hline Japan & 17 & 0.7 & 18 & 77 \\
\hline Netherlands & 4 & 5.3 & 7 & 247 \\
\hline Norway & 1 & 9.6 & 1 & 895 \\
\hline Portugal & 8 & 4.2 & 15 & 170 \\
\hline Spain & 2 & 8.0 & 3 & 375 \\
\hline Sweden & 16 & 1.3 & 5 & 293 \\
\hline UK & 19 & -0.6 & 19 & 71 \\
\hline United States & 14 & 2.1 & 11 & 223 \\
\hline
\end{tabular}

Source: calculations based on Frederiksen (2001). 
The following Figure qualitatively depicts the relationship between pension expenditure projections and the various definitions of pension liabilities, where liabilities are as defined in Box 4 (accrued-to-date liabilities are given by $\mathrm{LP}(\mathrm{t})+\mathrm{LW} 1(\mathrm{t})$; future gross benefits of current and perspective workers are $\mathrm{WFB}(\mathrm{t})$ and $\mathrm{FWB}(\mathrm{t})$, respectively). In particular, at a given point in time (time A) accrued-to date liabilities are going to die out as the last pensioner exits the system; later on workers' future benefits will start to decline while, in the case of open systems, liabilities will keep growing.

Figure 1

\section{Expenditure Projections and Pension Liabilities}

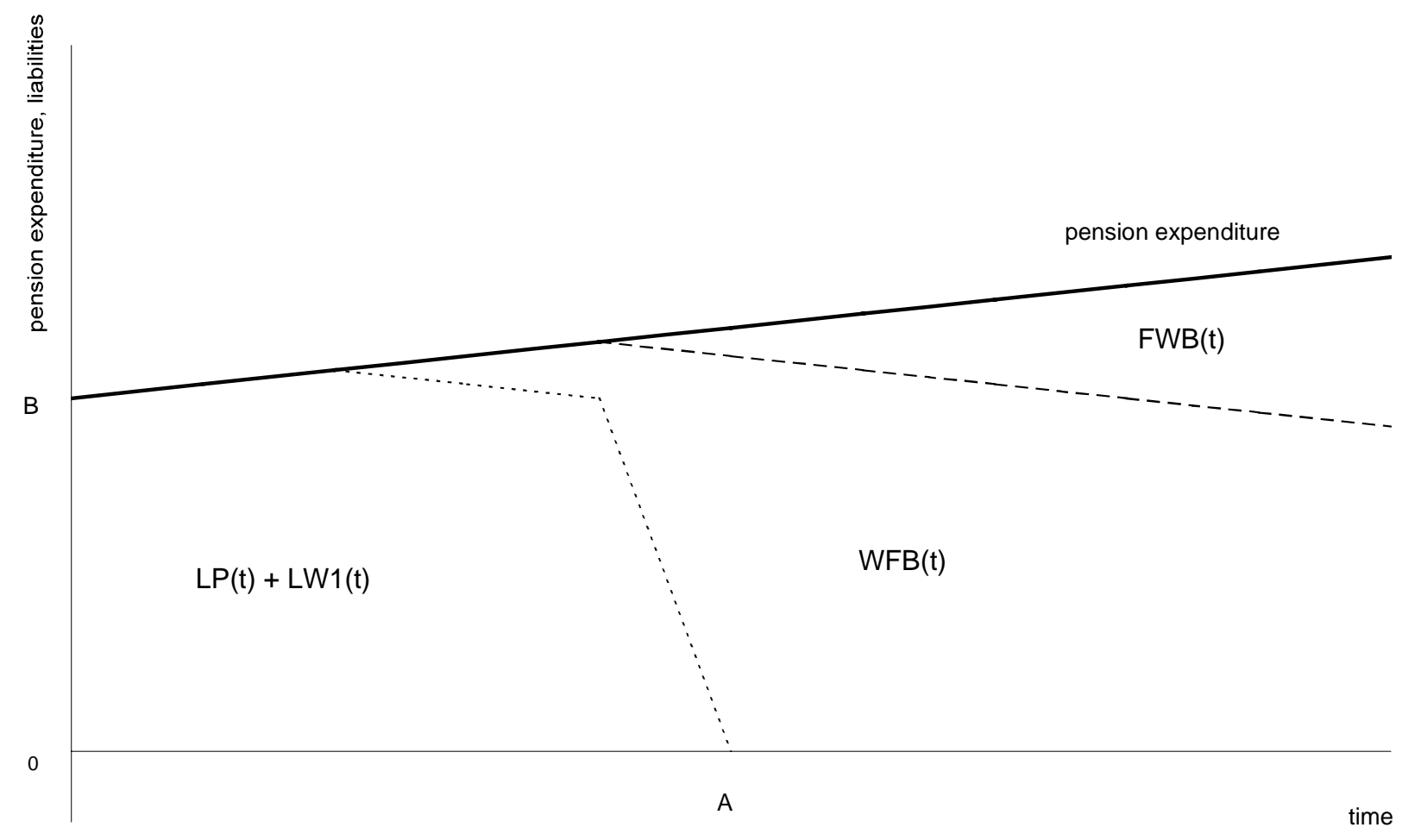

To better understand the relationship between pension liabilities and pension expenditure it would be advisable to distinguish between expenditure components, i.e. between expenditure relating to accrued liabilities, to future liabilities of current workers and to future liabilities of perspective workers. The composition of pension expenditure projections can provide information on the feasibility of pension reforms: the larger the accrued component the less likely reforms are and, if implemented, less likely reforms are to be effective (as they are likely to deal with the not-yetaccrued-component). 
In addition it could also be advisable to compute not only expenditure projections but also liabilities projections, especially with reference to the accrued-to-date definition. Indeed, the stability of such projections can indicate that the system is not likely to run into problems. The opposite holds, if such projections are on an increasing path.

Consequently, it would be advisable to have information concerning all the three liabilities' definitions as they provide different types of hints.

The use of expenditure projections or of the different definition of pension liabilities depend on the issue to be examined.

5.1 Evaluating the overall impact of ageing. - Although pension schemes are likely to exert the greatest strains on developed countries' budgets in the next few decades, a wider approach is required in the assessment of the effects of ageing. Demographic changes will actually influence most expenditure items: population ageing will increase health care expenditure since the consumption of services raises steeply with age; it will also increase the demand for some social services; the decline in the number of young people will provide an opportunity to reduce education expenditure; the decline in total population growth, and in some countries the decline of total population, might reduce the requirements for capital expenditure.

Fiscal sustainability should be assessed with an accounting framework that considers all budgetary items. $^{66}$ Pension expenditure projections can be easily combined with projections for other budgetary items. On the contrary, referring to liabilities rather than to spending would be problematic with reference to health, long-term care, welfare and education outlays.

Moreover, netting out of earmarked contributions is not relevant when assessing the overall sustainability of fiscal policy. It discriminates against systems which finance pension expenditure also with general taxation (and not only contributions). ${ }^{67}$

5.2 Evaluating the sustainability of pension schemes. - The pension expenditure-to-GDP ratio and the contribution rate that assure the cash balance of pension schemes give straightforward indications concerning sustainability. On the other hand, neither the size of accrued liabilities nor those of present pensioners' and workers' liabilities and open system liabilities indicate whether the schemes are sustainable (see Section 4).

Moreover, age-related expenditure projections can provide more intuitive indications than liabilities measures and are less sensitive to underlying assumptions. Small changes in starting conditions and

See Auerbach et al. (1991) and Kotlikoff (1992).

67 The CBO (2004) stresses that "the term "unfunded liability" has been used to refer to a gap between the government's projected financial commitment under a particular program and the revenues that are expected to be available to fund that commitment. But no government obligation can be truly considered "unfunded" because of the US government's sovereign power to tax - which is the ultimate resource to meet its obligations." 
assumptions can determine large shifts of pension liabilities (EPC, 2003). Moreover, as all liabilities' measures are a stock measure based on present value calculations they share the drawback of being highly sensitive to changes in the discount rate. Moving to flow variables can allow to get rid of this latter problem.

However, liability measures can provide other types of information. Accrued liabilities indicate the cost of closing the scheme. Open-system liabilities, which include new net expected pension rights, provide a measure of the difference between the implicit return on contributions to PAYG schemes and some rate of return assumed as a benchmark. Estimates of new net rights do not provide any measure of present and future cash imbalances, nor do they provide information on the need to adjust contribution rates or benefit rules, or on pressures on the budget.

5.3 Trading future reforms with higher current deficits. - Within the European debate on the effectiveness of the Stability and Growth Pact, several proposals to render fiscal soundness and structural reforms compatible have been put forward. In November 2002 the European Commission stressed that, for countries which have already made substantial progress towards the achievement of the medium-term target set by the Stability and Growth Pact, a small and temporary deterioration in the underlying budget position could be envisaged in the face of structural reforms.

Applying this idea to pension reforms means "trading" a temporary worsening in today's fiscal balance for a reduction in future deficit and debt via a reform of the pension system: once a country had put structural reforms into effect, the medium-term target would be modified accordingly.

Suppose that a country is allowed to worsen its deficit at time $t$ in the face of commitments to reduce its debt below a certain threshold by time $t+T$ via a pension reform. The assessment of this "trade" could be dealt with in two ways.

First, as each period debt is the previous period debt plus current deficit, one can estimate the reduction in pension expenditure due to the reform and so the corresponding improvement in future deficits and so the new debt development path which guarantees a certain debt level at time $t+T$.

Alternatively, one can estimate the change in future liabilities due to the reform (i.e. the discounted flow of changes in pension spending). Nevertheless, this second solution is not easy to deal with as it is not straightforward to assess the relationship between deficit, conventional debt and pension liabilities. Therefore, referring to pension expenditure rather than to pension liabilities seems more intuitive and easier to implement.

5.4 Evaluating the impact of pension wealth. - Pension liabilities can be more effectively used to evaluate the fiscal impact on consumption and saving ratios, of deficits in accrual terms, and of the economic balance of pension schemes.

As present pensioners' and workers' liabilities basically correspond to social security wealth, they are relevant for the assessment of fiscal effects on saving decisions. Furthermore, they highlight the future cost of present pension policies and they may reduce the incentive "for fiscal authorities to 
substitute away from cash to non-cash activities as a means of circumventing constraints on the overall cash-based deficit or expenditure". ${ }^{6}$

\section{Further progress is needed}

A broad assessment of fiscal sustainability in EU countries requires complementing the current deficit and debt indicators with forward-looking indicators. In this context, estimates of the impact of the pension system on the budget are necessary. This can be achieved either via projections of future pension spending or via estimates of pension liabilities. In the previous Section we have examined the different properties of the two indicators and have argued that the use of expenditure projections or of the different definition of pension liabilities depend on the issue to be examined. We have also underlined that pension expenditure projections seem the most appropriate tool for sustainability analysis.

As noted in Section 3, the availability and quality of pension expenditure projections in the EU have greatly improved but there remain significant problems, which hampers their use in assessing fiscal sustainability. In particular, projection comparability among EU countries is still unsatisfactory. Furthermore, progress is still required both in the organisation of projections and in their technical features both at the national and at the EU level.

Improvements in the quality of pension expenditure projections would also enhance the quality of estimates of pension liabilities.

6.1 Organisation aspects. - In a rapidly changing demographic context, where reforms of social policies continue to be politically problematic, more attention needs to be paid to the way in which projections are organised, in particular to the attribution of responsibilities, to the accountability requirements and to the frequency and transparency of the exercises. The availability of accurate long-term projections is a necessary condition for the efficient design of social policy.

Projections indicating a significant increase in future spending necessarily trigger discussion of reform. By contrast, the lack of projections can allow reforms to be avoided or deferred. In the end, only if public opinion has sufficient awareness of future long-term obligations will reform be politically practicable (Boeri et al., 2000).

In light of the greater role that long-term sustainability is going to play in the EU fiscal framework, in principle the most appropriate solution would be to assign the responsibility for pension expenditure and pension liabilities estimates to a unique institution at the EU level. This solution, which would ensure the comparability of national projections, raises two problems. First, it would require that all EU countries agree on a common method and accept a certain the loss of 
sovereignty. Second, on a more technical ground, a unified forecasting authority and a common method may imply losses in terms of details and quality of projections. This problem can be dealt with only if a close link is established between the new institution and the national authorities in order to allow the former to benefit of the expertise of the latter.

An alternative solution would be that of retaining the current responsibility of national institutions while strengthening the coordination concerning the organisation of projections. This is the approach followed so far at the EU level. Tighter common guidelines and greater peer pressure would increase comparability and transparency. A step in this direction is envisaged for the 2005 projection exercise of the AWG. However, additional efforts need to be made in eliminating differences in coverage, models and techniques. Adjustments for individual country specific circumstances should be kept to a minimum. Allowed differences should be explained in detail and motivated.

The following general points apply to both organisational scenarios.

Responsibility and accountability for the exercises. - Both expenditure projections and pension liability estimates should be detached from policy considerations and from country specific interests. The agencies assigned to produce forecasts should not be those responsible for fiscal and social policy. Ideally, forecasts should be assigned to a technical agency that answers directly to Parliament.

An alternative solution would be the coexistence of a number of different public and private forecasting institutions. In this case, no monopoly on data should be allowed and the costs of running forecasting models should be lowered. This could be achieved by requiring the public agencies that hold data to make them promptly available to all interested parties. Forecasting models developed in the public sector should be made available to all possible users.

Frequency of projections. - Forecasts should be made on a regular basis (for instance every two or three years), not in connection with political evaluation of the effects of specific reforms. ${ }^{69}$ This would enhance the credibility of projections.

Transparency. - Repetition of forecasting exercises inevitably means the revision of previous results. This may be due to changes in the demographic and economic framework or to changes in the model. ${ }^{70}$ Every exercise should have a detailed discussion of the reasons for the revision. This enhances transparency and heightens the incentive for accurate projections.

The results of the projections should be released in the form of analytical papers that allow for an assessment of the underlying assumptions and that include tests of sensitivity to demographic,

69 Castellino (1997) underscores the importance of repeating forecasting exercises.

70 Fornero (1997) suggests running the models "backwards" to see whether, using the actual values of the demographic and economic variables, they accurately "predict" spending. 
economic and behavioural variables. The reports should provide detailed information about different indicators. For instance, in the case of pension expenditure, both the ratio of outlays to GDP and the equilibrium contribution rate should be given. There should be detailed projections on the number of pensioners and the size of the average pension, broken down by type of pension and category of worker. In a system in which public pensions also provide income support to unemployed in working age, the preparation of consolidated accounts of social spending by age-groups would help to isolate and evaluate the functions actually performed by the pension system. Estimates of pension liabilities should also be provided, in particular concerning accrued liabilities.

6.2 Technical aspects. - The quality of pension expenditure projections has greatly improved in recent years. However, further progress is required in a number of areas.

Coverage. - Projections, as well as estimates of liabilities, should cover all pension schemes. In order to evaluate the overall effects of ageing, projections should cover also the other age-related public expenditure items, such as health, long-term care and education. In addition, one should aim at projecting also other expenditure items and revenue, in order to allow an assessment of the overall sustainability of the public finances.

Methodology. - Projections should be based on demographic scenarios prepared, for the sake of comparability, by Eurostat with the involvement of national statistical institutes. They should cover a period sufficiently long (at least 50 years) to let the size and age structure of the population to converge towards a new equilibrium level and to allow all persons currently in the labour force to retire. However, projections should also consider the non-demographic factors affecting pension spending, such as the composition of the workforce and the retirement decisions of individuals. ${ }^{71}$

Dealing with uncertainty. - Forecasting models are generally deterministic and the assumptions concerning demographic and economic variables are often based on their own past performance. This mainly reflects the difficulty of handling models that must consider many economic, demographic and behavioural factors and yet produce results quite quickly. Estimates are generally based on scenario analysis. ${ }^{72}$ The issue of evaluating uncertainty can be tackled in different ways. One can associate probabilities to forecast ranges stemming from alternative scenarios. ${ }^{73}$ One can also use stochastic simulations assigning a probability to an arbitrarily large sample of input

71 Additional efforts should be made in modelling public spending on health and long-term care taking into account also non-demographic factors (past expenditure trends, "death-related" costs, the degree of institutionalised provision of long-term care and the change in the health care status of older people).

72 This is only a first step towards a determination of the uncertainty in the estimates since projections do not usually incorporate any overall measures of probability for the input scenarios and therefore it is not possible to evaluate the likelihood of the results. This approach allows evaluating how results would be affected if all the values for inputs moved in the same direction even though remaining plausible. The high and low estimates serve as boundaries. 
combinations, solve for the system's finances under each set of paths and then use the probability associated with each set of inputs to create a probability distribution for the outputs. ${ }^{74}$

The data. - It is important that the data on which projections are based are frequently and regularly updated and promptly made available to forecasters. ${ }^{75}$ In particular, given the rapid evolution of family structures, the probabilities of the main family events need regular revisions. For instance, it would be useful to have a protocol whereby the institutions supplying the data needed for forecasting pledge to release them regularly. These factors must necessarily be considered in assessing the effects of changes in the role of the social protection system and in estimating the associated spending.

The underlying assumptions. - Every forecast is based on a large number of assumptions concerning demographic trends, economic variables and individual behaviour. It is obviously important that the projection reports make these assumptions explicit and describe their margin of uncertainty. Moreover, the reports should consider whether the simplifying assumptions ordinarily used in all projections are effectively justified. In age-related expenditure forecasts, for example, there should be greater attention to analysis of the main demographic and behavioural variables by cohort, to avoid simplistic assumptions producing unrealistic spending forecasts. ${ }^{76}$ In particular, one would need a careful evaluation of the estimates of survival for the very old (over 80), since it has been observed that those now available tend to overestimate mortality (Caselli, 1996, and National Research Council, 2001). The assumptions concerning family events (marriage, age and status of survivors, etc.) and individuals' behavioural choices need to be set out in detail. It would be helpful to have a breakdown by age, sex and year of forecast, of assumptions on the retirement probability of individuals in the retirement age bracket.

The labour market. - The level of pension spending depends on the evolution of the labour market. The equilibrium contribution rate critically depends on it. The key factors are the participation rates of older workers and of women. ${ }^{77}$ Spending forecasts should be based on studies concerning, for

74 In stochastic models, inputs take values based on random variables and final forecasts result from the application of Monte Carlo simulations (Meyerson and Sabelhouse, 2000; CBO, 2003). A stochastic approach solves some of the problems set out above but may complicate the forecasting process. It requires simulating several demographic processes for each year in the forecast concerning e.g. births, deaths, marriages, divorces and immigration. This may require developing a model for each of these processes and relate them with one another or develop a unique model containing all details at the cost of a higher simplification of reality.

75 For example, in recent Italian projections the Ragioneria Generale dell Stato uses data from INPS (1989) on the probabilities of key family events, even though it is well known that family trends in Italy have changed substantially in the intervening years. The number of households has increased, their average size has decreased and the number of persons living alone has increased.

76 In order to limit the gap between forecasts and outcomes, Lacasse (1994), Reynauld and Vidal (1994) and Strobel (1994) stress the importance of a correct identification of potential beneficiaries of the social programmes and of the study of their behaviour, since individuals may change their behaviour in order to be entitled to social benefits.

77 The importance of this is underscored in OECD (1995a and 1995b) and is made plain in the exercises conducted for Economic Policy Committee (2000) with reference to the "Lisbon Scenario". See also European Commission 
instance, the incentives to retire provided by social security rules, workers' retirement choices and the present and future health conditions of elderly citizens. ${ }^{78}$ Forecasts should be able to use data on career histories, earnings and marital status of individuals. The need to consider the retirement behaviour of individuals is accentuated by the tendency to allow individuals to freely decide their retirement age within a certain age bracket. ${ }^{79}$

Living standards. - Projections should provide the information needed to evaluate the overall standard of living of the elderly. In particular, they should specify the size of public pensions paid to various groups of citizens according to age, sex, place of residence and family status. ${ }^{80}$ The data on public pensions should be supplemented by those on private pension plans and other incomes to produce an assessment of the overall economic situation of retirees. Obviously, public pension programmes interact with public action in other areas of social protection. ${ }^{81}$ A reduction in public retirement provisions not offset by an increase in other incomes could trigger stronger demand for action and also for certain types of health care services. Only if these aspects are taken into account can one truly judge the social sustainability of social security rules or reforms. Studies of the overall economic situation of retirees, which requires microsimulation models, could be performed less frequently than spending projections and could be assigned to different agencies.

\section{Conclusions}

A growing concern about the sustainability of pension systems, health expenditure growth and rising welfare spending have urged many governments to produce long-term projections. In the last two decades, the latter have assumed an important role in the fiscal policy debate and in the formulation of public policy.

The procedures by which projections are forged and the content of projections are essential elements in social policy management and even more for pension policy.

(2000b). The question is also examined in Visco (2001). For a discussion of the linkage between labour market and the size of pensions in Italy, see Peracchi (1999).

78 This will require the formation of data banks which follow the evolution of various cohorts over time. On this see National Research Council (2001). Jimeno (2000) notes that without data on the employment and earnings history of individuals it is hard to evaluate the effects of reforms.

79 Peracchi et al. (2001) emphasise the importance of longitudinal surveys providing demographic and economic information.

80 For a study along these lines see Sartor (2001), who gives estimates of the equilibrium contribution rate for private sector employees and of the average pension of different age cohorts. Sartor used sample data and relates the results for the pension system to a generational accounting exercise.

81 This is taken into consideration in OECD (1999). 
Over recent years the availability and quality of long-term pension expenditure projections has been largely improved and resources assigned to them have been substantially increased. Projections are now available for all EU countries. Progress has been achieved in the comparability of national exercises.

Three main trends characterise the European scene as regards the long-term analysis of public budgets:

- the rapid spread of projection exercises to all countries and a tendency to conduct them on a regular basis, not contingent on reform proposals;

- the increasingly close linkage of the analysis of pension spending to the sustainability of public finances as a whole (the dynamics of pension expenditure is examined together with that of other items connected with demographic changes and with the dynamics of the budget balance and the public debt);

- the awareness that trends in pension spending, through their impact on the budget balance, have repercussions at EU level and, hence, the need for internationally comparable projections and for systematic monitoring of spending in each country.

However, the organisation, comparability and quality of projections still present several limitations. The national institutions assigned to make the projections are often those responsible for designing social policy, which may affect both the availability and the substance of the forecasts. National projections are produced with different models and coverage is not homogeneous. The information made public is often not sufficient for an adequate assessment of the forecasting exercises and for conducting alternative exercises.

Further efforts should therefore be devoted to pension projections both at the national and the EU level.

An appropriate measurement at the EU level requires not only common assumptions, but also common forecasting procedures and coverage. This requires further integration among national forecasting institutions.

Forecasts should cover a well-defined and long projection period and should be made on a regular basis. There is need for a detailed description of the assumptions and the results. Changes with respect to previous exercises should be explained. Furthermore, forecasts should be assigned to a technical agency that is not involved in the design of pension policy. Alternatively, projections should be carried out by a number of different public and private forecasting institutions. The data on which projections are based should be frequently updated and promptly made available to forecasters. The projection reports should specify all the underlying assumptions and allow a detailed assessment of the results. 
The pension-projection results should be expressed both in terms of expenditure-to-GDP ratios and equilibrium contributory rate and in terms of accrued liabilities.

The assessment of the sustainability of pension systems and the pressure of pension schemes on the budgets should primarily refer to expenditure to GDP ratios and equilibrium contributory rates. Pension liabilities should not be included in the deficit and debt measures used in evaluating current fiscal policy.

Estimates of pension liabilities may nevertheless represent a useful complement to conventional debt and deficit measures. They bring a clearer understanding of fiscal impact on consumption and saving ratios, and of some aspects of the economic situation of PAYG schemes. Namely, accrued liabilities are useful for the measurement of economic deficits. They also provide a measure of the cost of terminating PAYG pension schemes. Present pensioners' and workers' liabilities, which correspond to Social Security Wealth, are relevant for the assessment of fiscal effects on saving decisions. 


\section{References}

Aaron, H.J. (1966), “The Social Insurance Paradox", Canadian Journal of Economics and Political Sciences, XXXII, No. 3, pp. 371-374.

Artis, M. and M. Marcellino (2000), "The Solvency of Government Finances in Europe", in Banca d'Italia (2000).

Auerbach, A.J., J. Gokhale and L.J. Kotlikoff (1991), "Generational Accounts: A Meaningful Alternative to Deficit Accounting", in D. Bradford (ed.), Tax Policy and the Economy, Vol. 5, Cambridge Mass., pp. 55-110.

(1992), "Generational Accounting: A New Approach for Understanding the Effects of Fiscal Policy on Saving”, Scandinavian Journal of Economics, No. 94, pp. 303-318.

Balassone, F. and D. Franco (2000a), “Assessing Fiscal Sustainability: A Review of Methods with a view to EMU”, in Banca d'Italia (2000).

Balassone, F. and D. Franco (2000b), "Public Investment, the Stability Pact and the Golden Rule", Fiscal Studies, Vol. 21, No. 2, pp. 207-229.

Balassone, F. and D. Franco (2001), "EMU Fiscal Rules: A New Answer to an Old Question?", paper presented at the 3rd Banca d'Italia Workshop on Public Finance, Fiscal Rules, Perugia, 1-3 February 2001.

Balassone, F. and D. Monacelli (2000), “EMU Fiscal Rules: is there a Gap?”, Temi di Discussione, No. 375, Banca d'Italia.

Banca d'Italia (2000), Fiscal Sustainability, Rome.

Barro, R.J. (1974), “Are Government Bonds Net Worth?”, Journal of Political Economy, Vol. 82, No. 6, pp. 1095-1117.

Beveridge, W. (1942), Social Insurance and Allied Services, Cmd. No. 5404, London, HMSO.

Blanchard, O., J.C. Chouraqui, R.P. Hagemann and N. Sartor (1990), “The Sustainability of Fiscal Policy: New Answers to an Old Question", OECD Economic Studies, No. 15, pp. 7-36.

Blanco Moreno, A., J. Montes Alonso and V. Antón Valero (2000), "Model for Simulating Expenditure Scenarios for Contributory Social Security Retirement Pensions", Documentos de Trabajo, SGAPRS-2000-01, Ministerio de Economia y Hacienda, Madrid.

Boeri, T., A. Brugiavini, R. Disney and F. Peracchi (2000), “An Appeal to President Prodi - The EC Should Make Sure that European Citizens Are Informed about the Long-term Sustainability of Their Pension Systems", Fondazione Rodolfo Debenedetti.

Bohn, H. (1992), "Budget Deficits and Government Accounting", Carnegie-Rochester Conference Series on Public Policy, Vol. 37, pp. 1-84.

Börsch-Supan, A. (1991), “Ageing Population: Problems and Policy Options in the US and Germany”, Economic Policy, April, pp. 104-39. 
Boskin, M.J. (1982), "Federal Government Deficits: Some Myths and Realities", American Economic Review, Paper and Proceedings, May, pp. 296-303.

Boskin, M.J., L.J. Kotlikoff, D.J. Puffert and J.B. Shoven (1987), "Social Security: A Financial Appraisal Across Generations and Within Generations", National Tax Journal, Vol. XL, pp. 19-34.

Brittan, S., (1993), “The Harmful Myth of Hidden State Debt”, Financial Times, December 13th.

Brunila, A. (2000), "Public Finances in the XXI Century: Limitations, Challenges and Directions of Reforms in Finland", in Banca d'Italia (2000).

Buchanan, J.M. (1958), Public Principles of Public Debt, Homewood, Ill., Richard D. Irwin. (1983), "Social Security Survival: A Public-Choice Perspective", Cato Journal, Vol. 3, No. 2, pp.339-353.

Buiter, W.H. (1985), “A Guide to Public Sector Debt and Deficits”, Economic Policy, 1, pp. 612-35.

Buiter, W.H., G. Corsetti and N. Roubini (1993), "Excessive Deficits: Sense and Nonsense in the Treaty of Maastricht", Economic Policy, 16, pp. 57-100.

Buti, M., D. Franco and H. Ongena (1997), "Budgetary Policies During Recessions - Retrospective Application of the Stability and Growth Pact to the Post-war Period", Recherches Economiques de Louvain, Vol. 63, No. 4, pp. 321-366.

Caselli, G. (1996), "Future Longevity Among the Elderly", in G. Caselli and A.D. Lopez (ed.), Health and Mortality among Elderly Populations, Clarendon Press, Oxford.

Castellino, O. (1985), “C'è un secondo debito pubblico (più grande del primo)?”, Moneta e credito, No. 149.

(1997), “Discussione della relazione: 'Il modello di previsione dell'INPS', Cinzia Ferrara”, presented at the conference Le previsioni della spesa per pensioni: metodologie a confronto, Istat, 1 December, Roma.

CBO Congressional Budget Office (2003), The Long-Term Budget Outlook, December.

(2004), "Measures of the US Government's Fiscal Position Under Current Law", August.

Chalk, N. and R. Hemming (2000), "Assessing Fiscal Sustainability in Theory and Practice", in Banca d'Italia (2000).

Chand, S. and A. Jaeger (1996), “Ageing Populations and Public Pension Schemes”, Occasional Paper, No. 147, IMF, Washinghton.

Charpin, J.M. (1999), "L'avenir de nos retraites - Rapport au premier ministre", La Documentation Française.

Chase, S. (1943), Where's the Money Coming From?, New York, Twentieth Century Fund. 
Cronin, D. and D. McCoy (2000), "Fiscal Sustainability when Time is on Your Side", in Banca d'Italia (2000).

Delbecque, B. and H. Bogaert (1994), "L'incidence de la dette publique et du viellissement démographique sur la conduite de la politique budgétaire: une étude théorique appliquée au cas de la Belgique”, Bureau du Plan - Planning Papers, No. 70, November.

De Viti De Marco, A. (1934), Principi di economia finanziaria, Torino.

Dilnot, A., R. Disney, P. Johnson and E. Whitehouse (1994), Pension Policy in the UK - An Economic Analysis, The Institute for Fiscal Studies.

Disney, R. (2001), "How Should We Measure Pension Liabilities in EU Countries?, in T. Boeri, A. Börsch-Supan, A. Brugiavini, R. Disney, A. Kapteyn and F. Peracchi (eds.), Pension: More Information, Less Ideology, Kluwer Academic Publisher, The Netherlands.

Domar, E.D. (1944), "The Burden of the Debt and the National Income", American Economic Review, December, pp. 798-827.

Economic Policy Committee (2000), Progress Report to the Ecofin Council on the Impact of Ageing Populations on Public Pension Systems, Brussels.

(2001), Budgetary Challenges Posed by Ageing Populations: The Impact on Public Spending on Pensions, Health and Long-term Care for the Elderly and Possible Indicators of the Long-term Sustainability of Public Finances, Brussels.

(2003), The Impact of Ageig Populations on Public Finances: Overview of Analysis Carried out at EU Level and Proposals for a Future Work Programme, Brussels.

Eichengreen, B. and J. Von Hagen (1996), "Fiscal Policy and Monetary Union: Federalism, Fiscal Restrictions, and the No-Bailout Rule", in H. Siebert (ed.), Monetary Policy in an Integrated World Economy - Symposium 1995, Tubingen, Mohr, pp. 212-231.

European Commission (2000a), Social Protection in Europe - 1999, Brussels.

(2000b), Communication from the Commission to the Council, to the European Parliament and to the Economic and Social Committee, Brussels.

(2003), How the Sustainability of Public Finances Was Assessed on the Basis of the 2002 Updates of the Stability and Convergence Programmes, Note for the attention of the Ageing Working Group of the EPC.

European Commission (2004a), Public Finance in EMU, Brussels.

(2004b), "Strengthening Economic Governance and Clarifying the Implementation of the Stability and Growth Pact", Communication to the Council and to the European Parliament, No. 581, 3 September.

Feldstein, M. (1974), "Social Security, Induced Retirement, and Aggregate Capital Accumulation”, Journal of Political Economy, September-October. 
Fernandez, F. and P. de Cos (2000), "On the Sustainability of the Spanish Public Budget Performance", in Banca d'Italia (2000).

Fornero, E. (1997), “Osservazioni sulla relazione: 'I modelli di previsione del sistema pensionistico elaborati dalla Ragioneria Generale dello Stato' by Rocco Aprile", presented at the conference Le previsioni della spesa per pensioni: metodologie a confronto, Istat, 1 December, Rome.

Fornero, E. and O. Castellino (eds.) (2001), "La riforma del sistema previdenziale italiano : opzioni e proposte", Rapporto CeRP.

Franco, D. (1995), "Pension Liabilities - Their Use and Misuse in the Assessment of Fiscal Policies", Economic Papers, European Commission, No. 110.

Franco, D. and M.R. Marino (2003), "The Role of Forecasts in Social Security Policy", Giornale degli Economisti e Annali di Economia, Vol. 61, No. 2, December.

(2004), "The Role of Long-term Fiscal Projections", paper presented at the Workshop on Long-term Fiscal Projections, CentrA, Seville, 12-13 February.

Franco, D. and T. Munzi (1996), "Public Pension Expenditure Prospects in the European Union: A Survey of National Projections", in "Ageing and pension expenditure prospects in the Western world", European Economy, No. 3. No. 4.

Fredriksen, N.K. (2000), "Fiscal Sustainability and Tax Smoothing: A Preliminary Analysis of the case of Denmark", in Banca d'Italia (2000).

(2001), "Fiscal Sustainability in the OECD. A Simple Method and Some Prelimininary Results", Finansministeriet Working Paper, No. 3/2001.

Griziotti, G. (1917), "La diversa pressione tributaria del prestito e dell'imposta”, Giornale degli Economisti, March.

Jensen, J. (2001), “New Zealand's Fiscal Policy Framework: Experience and Evolution”, paper presented at the 3rd Banca d'Italia Workshop on Public Finance, Fiscal Rules, Perugia, 1-3 February.

Jimeno, J.F. (2000), "The Spanish Pension System: Medium-term Perspectives", paper presented at the conference Public Pensions Reforms and the Labor Market, Brescia, 20-21 October.

Hagemann, R.P. and G. Nicoletti (1989), “Ageing Populations: Economic Effects and Implications for Public Finance”, OECD Department of Economics and Statistics Working Paper, No. 61.

Hansen, A.H. (1941), Fiscal Policy and the Business Cycle, Norton \& Co., New York

Hautala, U. and J. Tuukkanen (2000), “Towards a Sustainable and Job-Oriented Pension System in Finland", in Banca d'Italia (2000). 
Heller, P.S., R. Hemming and P. Kohnert (1986), “Ageing and Social Expenditures in the Major Industrialized Countries, 1980-2025”, IMF Occasional Paper, No. 47.

Heller, P.S. (2003), Who Will Pay? Coping with Aging Societies, Climate Change, and Other Long-Term Fiscal Challenges, IMF, Washington D.C.

ILO (1997), Economically Active Population, Geneva.

INPS (1989), "Il Modello INPS e le Prime Proiezioni al 2010”, Supplemento Previdenza Sociale, No. 3, Rome.

Kilpatrick, A. (2001), "Transparent Frameworks, Fiscal Rules and Policy-making under Uncertainty", paper presented at the 3rd Banca d'Italia Workshop on Public Finance "Fiscal Rules", Perugia, 1-3 February.

Kinnunen, H. and P. Kuoppamaki (1998), "Sustainability of Public Finances in Finland and in the Four Largest Euro-area Economies", Bank of Finland Discussion Papers, No. 25.

Kotlikoff, L.J. (1984), "Economic Impact of Deficit financing”, Staff Papers, IMF, Vol. 33, pp. 549-581.

(1992), Generational Accounting - Knowing Who Pays, and When, for What We Spend, New York, Free Press.

Kuné, J.B., W.F.M. Petit and A.J.H. Pinxt (1993), “The Hidden Liabilities of Basic Pension Systems in the European Community", CEPS Working Document, No. 80, November.

Kuné, J.B. (1996), “The Hidden Liabilities: Meaning and Consequences”, revised version of a paper presented at the CPB Seminar Series, 26 November, The Hague.

Lacasse, F. (1994), "Issues and Choices for the International Study of Transfer Policies", in OECD, Forecasting and Controlling Transfer Programme Costs: Definition and Methods, Public Management Occasional Papers, No. 7.

Leeftink, B. (2000), "Rules Versus Flexibility: Does the Stability Pact Limit Budgetary Flexibility?", in Banca d'Italia (2000).

Leibfritz, W. (2000), “Generational Accounting Around the World”, in Banca d'Italia (2000).

Leibfritz, W., D. Roseveare, D. Fore and E. Wurzel (1995), “Ageing Populations, Pension Systems and Government Budgets: How Do They Affect Saving?", OECD Working Paper, No. 156, Paris.

Lerner, A.P. (1943), "Functional Finance and the Federal Debt", Social Research, No. 10, pp. 38-51.

Lindh, Y. and H. Ohlson (2000), "Long-term Developments of Swedish Public Finances - Can 'Straight Jackets' Reverse the Trends?", in Banca d'Italia (2000).

Mackenzie, G.A. (1989), “Are All Summary Indicators of the Stance of Fiscal Policy Misleading?”, IMF Staff Papers, Vol. 36, No. 4, pp. 743-770. 
Meyerson, N. and J. Sabelhouse (2000), "Uncertainty in Social Security Trust Fund Projections", National Tax Journal, Vol. LIII, No. 3, part 1, September.

Mink, R. and M. Rodriguez-Vives (2004), "Government Deficit and Debt in Economic and Monetary Union", paper presented at the XVI Villa Mondragone International Economic Seminar, Rules, International Economy and Growth, CEIS-University of Rome "Tor Vergata", 23-24 June.

Ministry of Economic Affairs of Denmark (2000), A Sustainable Pension System, Copenhagen, June.

National Research Council (2001), Preparing for an Ageing World - The Case for Cross-national Research, National Accademy Press, Washington, D.C.

Netherlands Bureau for Economic Policy Analysis (2000), Ageing in the Netherlands, The Hague.

OECD (1985), Social Expenditure 1960-1990 - Problems of Growth and Control, Paris.

(1988), Ageing Populations - The Social Policy Implications, Paris.

(1988b), Reforming Public Pensions, Paris.

(1992), Private Pensions and Public Policy, Paris.

(1993), “OECD Health Systems - Facts and trends 1960-1991”, Vol. 1, Health Policy

Studies, No.3, Paris.

(1995a), “The Transition from Work to Retirement”, in Social Policy Studies, No. 16. (1995b), “The Labour Market and Older Workers”, in Social Policy Studies, No. 17.

(1996), "Ageing in OECD Countries - A Critical Policy Challenge”, Social Policy

Studies, No. 20. (1999), Benefits Systems and Work Incentives, Paris.

(2001), "Fiscal Implications of Ageing: Projections of Age-related Spending", Economic Outlook, June.

Oksanen, H. (2004), Public Pensions in National Accounts and Public Finance Targets, European Economy Economic Papers, July.

Pasinetti, L. (1997), "European Union at the End of 1997: Who Is Within the Public Finance 'Sustainability' Zone?’, Lezione Lincea 'Luigi Einaudi'.

Pearson, M., S. Smith and S. White (1989), "Demographic Influences on Public Spending", Fiscal Studies, No. 2.

Peracchi, F., E. Barbi, A. Brugiavini, T. Tamborrini and E. Viviano (2001), "Completezza e qualità delle informazioni statistiche utilizzabili per la valutazione della spesa pensionistica", Commissione per la Garanzia dell'Informazione Statistica, Presidenza del Consiglio dei Ministri, Rapporto di Ricerca, No. 01.01, January. 
Penner, R.G. (1982), "How Much is Owed by the Federal Government?", Carnegie-Rochester Conference Series on Public Policy, No. 16, pp. 233-256.

Premchand, A., (1983), Government Budgeting and Expenditure Controls: Theory and Practice, IMF, Washington.

Puviani, A. (1903), Teorie dell'illusione finanziaria, Palermo.

Reynauld, A. and J.P. Vidal (1994), "Forecasting the Costs of Social Tranfer Programmes for Individuals and Families", in OECD, Forecasting and Controlling Transfer Programme Costs: Definition and Methods, Public Management Occasional Papers, No. 7.

Rizzo, I. (1985), "Note su una definizione del concetto di debito pubblico", Rivista di diritto finanziario e scienza delle finanze, No. 1, pp. 185-204.

Robinson, M. (2001) "National and State Fiscal Rules in Australia: An Outline and Critical Analysis", paper presented at the 3rd Banca d'Italia Workshop on Public Finance, Fiscal Rules, Perugia, 1-3 February.

Roseweare, D., W. Leibfritz, D. Fore and E. Wurzel (1996), “Ageing Populations, Pension Systems and Government Budgets: Simulations for 20 OECD Countries", OECD Economics Department Working Papers, No. 168.

Rossi, S. and I. Visco (1994), "Private Saving and Government Deficit in Italy", in A. Ando, L. Guiso and I. Visco, Saving and the Accumulation of Wealth, Cambridge University Press.

Sartor, N. (1993), "On the Role of Budgetary Policies During Demographic Changes", Supplement to Public Finance - Finances Publiques, Vol. 48, pp. 217-227.

(2001), "The Long-run Effects of the Italian Pension Reforms", International Tax and Public Finance, Vol. 8, No. 1, pp. 83-111.

Scitovsky, T. (1961), “The Burden of the Debt: Comment”, American Economic Review, March, pp. $137-8$.

Shaviro, D. (1997), Do Deficits Matter?, The University of Chicago Press.

Strobel, P. (1994), "Social Policies: Adjustment, Drift and Equity", in OECD, Forecasting and Controlling Transfer Programme Costs: Definition and Methods, Public Management Occasional Papers, No. 7.

Tabellini, G. (1990), “A Positive Theory of Social Security”, CEPR Discussion Paper, No. 394, April.

Tanzi, V. (2000), "Globalisation and the Future of Social Protection”, IMF Working Paper, No. 12.

Technical Panel on Assumptions and Methods (1999), Report to the Social Security Advisory Board, p. 32, November.

Towe, C.M. (1991), "The Budgetary Control and Fiscal Impact of Government Contingent Liabilities", IMF Staff Papers, Vol. 38, No. 1. 
Van den Noord, P. and R. Herd (1993), "Pension Liabilities in the Seven Major Economies", OECD Economics Department Working Papers, No. 142.

Vanston, N. (2000), “Comment”, in Banca d'Italia (2000).

Visco, I. (2001), "Paying for Pensions: How Important is Economic Growth?", paper presented at the conference Managing the Global Ageing Transition - A Policy Summit of the Global Ageing Initiative, Zurich, 22-24 January.

Wendorff, K. (2001) "Remarks on the Discussion Concerning a National Stability Pact in Germany", paper presented at the 3rd Banca d'Italia Workshop on Public Finance, Fiscal Rules, Perugia, 1-3 February.

World Bank (1994), Averting the Old Age Crisis, Oxford University Press.

West, E.G. (1975), "Public Debt Burden and Cost Theory”, Economic Inquiry, No. 13, pp.179-90.

Zweifel, P., S. Felder and M. Meier (Institute for Empirical Research in Economics, University of Zurich) (1995), "Ageing of Population and Health Care Expenditure: A Red Herring?", paper presented to the International Conference Ageing and Old-Age Econometrics, Health Care Econometrics - IX, University of Athens, May 18-19. 


\section{ANNEX 1 \\ Long-term public expenditure projections}

Long-term fiscal projections were carried out as early as in 1942 when a 30 year estimate of social expenditure in the UK was included in the Beveridge Report. However, it is from the mid-1980s, when it became apparent that Western countries were experiencing major changes in their demographic structure, that an increasing number of studies have examined the long-term prospects for public budgets (Heller, 2003). This development is related to the growth of legislated policy commitments in social insurance, to better capacity of modelling and simulating economic trends and to the public debate on demographic issues.

Two lines of research have been followed. Many studies evaluated the prospects of the main agerelated expenditure programs and produced projections of the ratio of age-related expenditure to GDP. Other studies aimed at developing synthetic indicators of the long-term fiscal performance.

The studies examining the prospects of expenditure programmes focus on budget items particularly dependent on population age structure, such as pension, health and education spending. The basic intuition is that citizens of different sex and age groups receive from government different amounts of services and transfers. In these studies data on per capita public spending for different age-groups and for different budgetary items are combined with demographic projections. Some studies only consider the effects of demographic changes, while others also try to capture some nondemographic factors such as pension scheme maturation and long-term trends towards higher health expenditure.

Mechanical projections of the effects of demographic changes. - The most basic approach provides estimates of the effects of demographic changes on public expenditure under the assumption that age-related per capita expenditure levels remain constant over the projection period in real terms or in per capita GDP terms. In other words, it is assumed that present standards of transfers and services are maintained for all population age-groups and that there is no behavioural response from governments or households to demographic changes and their budgetary effects.

Age-related expenditure profiles thus form the building block of studies evaluating the impact of changing demographics on public expenditure. They are computed by estimating the average amount spent for members of each sex and age group on the basis of administrative data or economic surveys (Franco and Munzi, 1997). The profiles for the base year can be combined with the future expected structure of the population in order to evaluate the mechanical impact of demographic changes on public spending.

Expenditure profiles for different budgetary items can be projected into the future on the basis of the assumption that expenditure for the members of each age group increases at a yearly rate equal to the rate of growth of GDP per worker or to the rate of growth of per capita GDP. The former assumption is reasonable for expenditure items mostly represented by wages. The latter is 
reasonable for transfers. The two assumptions lead to different estimates when the ratio of workers to citizens changes.

Estimates combining data on per capita expenditures for different age-groups and for different budgetary items with demographic projections are only indicative measures of the likely effects of demographic change on public expenditure, since they do not take all relevant effects of demographic changes into account. ${ }^{82}$

First, mechanical estimates are based on the implicit assumption that the marginal cost of providing services to a smaller or a larger number of individuals in each age group in the future will be equal to the present average cost of these services (Pearson et al., 1989). In other words, it is assumed that there are no economies or diseconomies of scale in the production of public services. This assumption is surely implausible over relatively short periods, because of time lags in the adjustment of inputs to changes in the demand for public services.

Second, mechanical estimates implicitly assume that demographic changes do not modify present age-related per capita expenditure levels, while they can actually affect them through many different channels (Pearson et al., 1989). Demographic changes can influence the cost of inputs used in services (e.g., a relative shortage of young workers may increase the cost of public services employing them) and the demand for some services (e.g., a reduction in the number of children per household may, in the long run, increase the demand for elderly care). They can also affect productivity trends, wage rates and saving ratios. ${ }^{83}$

While the failure to consider economies and diseconomies of scale may compromise short-period estimates, that concerning system-wide effects may affect long-period estimates.

Moreover, it should be stressed that demographic change is just one of the several factors affecting public expenditure dynamics. The contribution of mechanical estimates of the effects of demographic changes to the assessment of the prospects for public expenditure is therefore necessarily limited.

Projections considering non-demographic changes. - Once non-demographic factors are taken into consideration, there is no reason why age-related per capita expenditure levels remain constant in real terms or in per capita GDP terms on the initial level over the projection period. Standards of transfers and services will change over time.

82 This point is made in OECD (1988), pp. 27-28.

83 The use of current per capita age-profiles to project expenditure levels is particularly problematic for health care. Several studies note that a sizeable share of health expenditure occurs in the final part of life. This implies that the number of deaths occurring each year also affects expenditure. It also implies that an increase in life expectancy may have limited effects on lifetime health expenditure. See Zweifel et al. (1995). 
While several economic, political and social factors can obviously affect the dynamics of per capita transfers and services, the studies examining the prospects of age-related expenditure usually focus only on three specific factors: the effects of changes introduced in legislation, but not yet embodied in present expenditure profiles; the continuation of structural expenditure trends; and the effects of structural changes in the economy and society. These factors are considered because they are consistent with a constant policy approach, while there is usually no attempt to predict the effects of changes in behaviours and policies.

The effects of changes introduced in legislation, but not yet embodied in present expenditure profiles, are particularly relevant for pension expenditure projections, since pension eligibility and transfer ratios can change considerably over time due to the maturation of schemes, i.e. the process of adjustment of all pensions to present retirement rules. On the one hand, pension coverage extensions and benefit improvements usually only produce their full effects on the two ratios after many decades. On the other, quite often reforms curtailing pension benefits are implemented gradually and only display their full effects a long time later (OECD, 1988b). ${ }^{84}$

The continuation of structural expenditure trends (i.e., the assumption that some non-demographic factors relevant in the past would continue to affect expenditure dynamics in the future) is especially relevant for health care expenditure projections. In several countries the health sector has for long periods recorded a price deflator substantially higher than the GDP deflator and a tendency towards a continuous increase in per capita consumption. ${ }^{85}$

Projections can also forecast the effects of structural changes in economic structure, labour market and household composition. The basic idea is that entitlement to and provision of public transfers and services depend on certain characteristics of citizens. For instance, a change in the composition of employment can affect spending for unemployment benefits. A change in the number of single parents or in the number of elderly living alone can affect the demand for welfare services.

Projections integrating the mechanical effects of demographic changes with estimates of some additional factors influencing pension and health expenditure were produced by the IMF in 1986 for the seven main Western economies (Heller et al., 1986). The growth in the number of pensioners and the dynamics of the average pension were projected taking the maturity of the different systems into consideration. As to health expenditure, the study outlined a scenario in which average medical costs were rising more rapidly than productivity.

84 Therefore, the assumption that age-related per capita expenditure levels remain constant is not equivalent to a constant policy assumption. It implies that all the effects of changes introduced in legislation are reflected in present age-related per capita expenditure levels.

85 OECD (1993) decomposed nominal health care expenditure growth over the period 1980-1990 for the OECD area (11.8 per cent per year) into the effects of general inflation ( 8 per cent), medical specific inflation ( 0.7 per cent), and the increase in volume of services (2.9 per cent, of which 2.4 per cent was attributed to the increase in per capita services and only 0.3 per cent was due to the ageing process). 
The overall impact of ageing populations on government budget was also examined in the studies carried out by OECD in 1995-96 (see Leibfritz et al., 1995, Roseveare et al., 1996 and OECD, 1996) and by the European Commission in 1997 (see Franco and Munzi, 1997). Growing awareness of population ageing has also led to a substantial increase in the resources devoted to national longterm public expenditure projections. Most developed countries now have long-term projections of pension spending and, in some cases, also of expenditure on health care and other budget items linked to the demographic structure. ${ }^{86}$

Projection models. - The forecasting models currently in use were developed gradually as needs for knowledge emerged. They employ a wide variety of methodologies. In moving from the mechanic projection of changes in the age-structure of the population to the assessment of several economic and social factors, the models have gradually become more complex. The projection of individual expenditure items has frequently been replaced by a wider analysis of the evolution of the public finances as a whole in a macroeconomic framework.

The models are generally deterministic and based on microdata such as sample surveys of the population or administrative data supplied by social security administrations. With a view to past performance, assumptions are made on the level of fertility, change in mortality, immigration levels, wages, unemployment rates, productivity and inflation rate.

Models are often organised in different modules: a first one for projecting the evolution in population; a second one directed to grouping people on the basis of their characteristics relevant to projections; a third one which actually projects long-term age-related expenditure. Some countries developed models finalised to project only some expenditure items dependent on the age structure; other countries have models aimed at evaluating the effects of ageing on the overall public finances.

Projection results are obviously tentative given the uncertainty of the underlying demographic and economic scenarios and the specification of the models, which tend to be as simplified as possible. The latter aspect reflects the twofold necessity of handling models that must contemplate many economic, demographic and behavioural factors and allow for the production of simulations over relatively short periods of time. In order to deal with the uncertainty issue, several scenarios matching different set of assumptions are frequently considered (baseline scenario, more favourable scenario, less favourable scenario).

Dynamic microsimulation models allow to consider the interaction of a number of economic and demographic factors. They provide indications concerning both expenditure trends and other factors, such as the evolution of income, wealth and family status of individuals. This may give a broader view of the sustainability of current policies. For instance, a reduction of public pensions may be considered sustainable if it is offset by an increase in other sources of income of the elderly. 
Stochastic models have also been developed over recent years. In this case, inputs take values based on random variables and the final forecasts, based on iterated simulations of the model, reflect the distribution of results (Meyerson and Sabelhouse, 2000). Demographic and economic inputs are allowed to vary throughout the forecasting period according to inferences based on historical data. Stochastic approaches give a better insight of the interaction of different factors. The forecasting process becomes more complex. ${ }^{87}$

87 Stochastic models require the simulation of many demographic processes for each year in the forecast (e.g., the number of births and their distribution by sex; the distribution of marriages and divorces by age-group and sex; immigration by age and sex) jointly with the economic performance. This requires the construction of a model for each of these processes and interrelations relating each of them with one another and with the underlying economic model. 